\title{
Cyclopalladated Benzophenone Imines: Synthesis, Antitumor Activity, Cell Accumulation, DNA Interaction, and Cathepsin B Inhibition
}

Joan Albert, ${ }^{*}, \dagger, \perp$ Jaume Granell ${ }^{\dagger}, \perp$ Romana Qadir, ${ }^{\dagger}$ Josefina Quirante, ${ }^{\dagger,} \perp$ Carme Calvis, ${ }^{\S}$ Ramon Messeguer, ${ }^{\S}$ Josefa Badía,,${ }^{\perp} \perp$ Laura Baldomà,,$\| \perp$ Mercè FontBardia, , , and Teresa Calvet ${ }^{\#}$

${ }^{\dagger}$ Departament de Química Inorgànica, Facultat de Química, Universitat de Barcelona, Martí i Franquès 1-11, 08028 Barcelona, Spain

Laboratori de Química Orgànica, Facultat de Farmàcia, Universitat de Barcelona, Av. Joan XXIII s/n, 08028 Barcelona, Spain

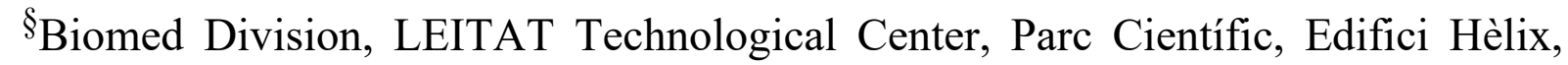
Baldiri Reixach 15-21, 08028 Barcelona, Spain

"Departament de Bioquímica i Biologia Molecular, Facultat de Farmàcia, Universitat de Barcelona, Av. Joan XXIII s/n, 08028 Barcelona, Spain

${ }^{\perp}$ Institut de Biomedicina, Universitat de Barcelona, 08028 Barcelona, Spain

\#Departament de Crystallografia, Mineralogia i Dipòsits Minerals, Universitat de Barcelona, Martí i Franquès s/n, 08028 Barcelona, Spain

IUnitat de Difracció de Raigs-X, Centre Científic i Tecnològic de la Universitat de Barcelona, Solé i Sabarís 1-3, 08028 Barcelona, Spain 


\section{ABSTRACT:}

The synthesis of the endo five-membered cycloortho-palladated benzophenone imines [Pd $\{\mathrm{C} 6 \mathrm{H} 4(\mathrm{Ph}) \mathrm{C}=\mathrm{NR}\}] 2(\mu-\mathrm{X}) 2$ [1 $(\mathrm{X}=\mathrm{OAc}), 2(\mathrm{X}=\mathrm{Cl}), \mathrm{a}(\mathrm{R}=$ phenyl), $\mathrm{b}(\mathrm{R}=1$-naphthyl $), \mathrm{c}(\mathrm{R}=$ benzyl), $d(R=\alpha$-methylbenzyl)], and trans-N,P-[Pd $\{\mathrm{C} 6 \mathrm{H} 4(\mathrm{Ph}) \mathrm{C}=\mathrm{NR}\} \mathrm{X}(\mathrm{PPh} 3)]$ [3 (X = OAc), $4(\mathrm{X}=$ $\mathrm{Cl}), \mathrm{a}(\mathrm{R}=$ phenyl $), \mathrm{b}(\mathrm{R}=1$-naphthyl $), \mathrm{c}(\mathrm{R}=$ benzyl $), \mathrm{d}(\mathrm{R}=\alpha$-methylbenzyl $)]$ and the $\mathrm{X}$-ray molecular structure of $1 \mathrm{a}, 1 \mathrm{c}, 1 \mathrm{~d}, 4 \mathrm{a}, 4 \mathrm{~b}$, and $4 \mathrm{c}$ are reported. The antitumor activity, DNA interaction, and cathepsin B inhibition of palladium compounds a-d were studied and compared with those previously reported for palladium compounds e with $\mathrm{R}=\mathrm{H}$ and compound $4 \mathrm{f}$ analogous to $4 \mathrm{e}$ but with a platinum(II) center. The IC50 values against a panel of human cancer cell lines allowed the establishment of a qualitative relationship between their structure and antitumor activity. Compounds $3 \mathrm{e}, 4 \mathrm{e}$, and $4 \mathrm{f}$ were the most active ones in relation to their in vitro anticancer activity. Compounds $3 \mathrm{e}$ and $4 \mathrm{e}$ were about 4 times more active than cisplatin against the MDA-MB-231 and MCF-7 breast human cancer lines, and compound $4 \mathrm{f}$ was about 4 times more active than cisplatin against the cisplatinresistant HCT-116 colon human cancer cell line. In addition, compound 3e was 3 times less cytotoxic than cisplatin toward the quiescent HUVEC cells. Accumulation of palladium compounds e and $b$ in the MDA-MB-231 cell line was considerably greater than that of cisplatin in the same cell line, but palladium compounds $b$ were noncytotoxic. Some of these complexes altered the DNA tertiary structure in a similar way to cisplatin but at higher concentration, and most cytotoxic ones did not present a high efficiency as cathepsin B inhibitors.

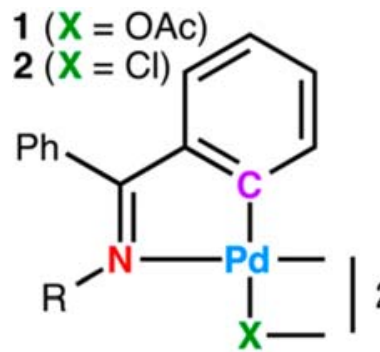

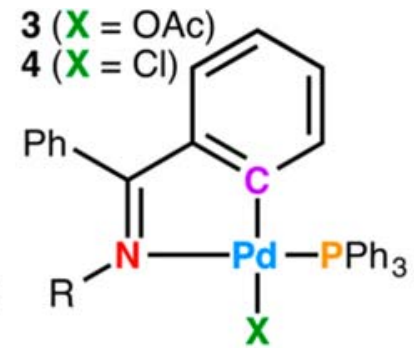<smiles>Cl[P]1(c2ccccc2)N=C(c2ccccc2)c2ccccc21</smiles>

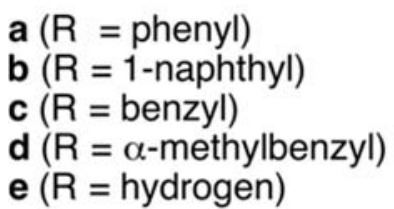

In vitro antitumor activity $3 \mathrm{e} \approx 4 \mathrm{e}>4 \mathrm{f}>2 \mathrm{e} \approx 1 \mathrm{e} \approx$ cisplatin $>2 \mathrm{~d} \approx$ $2 c \approx 2 a>3 a>$ other compounds (inactive or poorly active) 
60

\section{INTRODUCTION}

In recent years, coordination and organometallic palladium(II) compounds have been explored as an alternative to platinum-(II) compounds as anticancer drugs, in part due to the similarity of their substitution reactions.1,2 A significant difference between the two metal centers is the higher kinetic lability of palladium(II) compared to that of platinum(II). This renders palladium(II) less attractive for anticancer studies since hydrolysis of $\mathrm{Pd}-\mathrm{Cl}$ bonds is quite fast and gives way to very reactive species that are unable to reach the target biomolecules into the cancer cells. 3 In spite of this, the use of bulky monodentate ligands or chelate bidentate or terdentate ligands has provided palladium(II) compounds that are less reactive and with promising cytotoxicity against different cancer cell lines. 2

The cytotoxicity of a significant number of cyclopalladated compounds has been explored against a variety of cancer cell lines with interesting outcomes and with some chances of progressing for evaluation as drug candidates.4-20 For instance, compounds A and B in Figure 1 presented IC50 values against the B16-next2 murine melanoma cell line less than $1.25 \mu \mathrm{M}$. Compound B was the most potent in vivo, delaying tumor growth and prolonging animal survival in mice subcutaneously inoculated with the B16F10-Nex2 melanoma cell line. On the other hand, cyclopalladated compound $\mathrm{C}$ with a bridging 1,1'-bis(diphenylphosphane)ferrocene showed a notable cathepsin B inhibitory activity, with the potential to treat metastatic cancers.10-18 It should be noted that cyclopalladated compounds $\mathrm{A}-\mathrm{C}$ shown in Figure 1 were patented as antitumor drugs. 18

Recently, we have reported the synthesis of the cyclopalladated benzophenone imines $1 \mathrm{e}-4 \mathrm{e}$ and the cycloplatinated benzophenone imine $4 \mathrm{f}$ (see Scheme 1 for their structural formula), and we have studied their (i) antitumor activity toward MDA-MB-231 and MCF-7 breast and cisplatinresistant HCT-116 colon human cancer cell lines, (ii) interaction with pBluescript SK + plasmid DNA, (iii) cathepsin B inhibition test, and (iv) antibacterial and antioxidant activity.19,20 Noteworthy, compounds $3 \mathrm{e}$ and 4e were about 4 times more active than cisplatin against the MDA-MB-231 and MCF-7 human breast cancer lines, and compound $4 \mathrm{f}$ was also about 4 times more active than cisplatin against the cisplatinresistant HCT-116 human colon cancer cell line. In addition, compounds $1 \mathrm{e}-4 \mathrm{e}$ and $4 \mathrm{f}$ presented a moderate antibacterial and antioxidant activity. 20

Following these studies, we report herein the preparation of cyclopalladated benzophenone imines a-d (Scheme 1) and the study of (i) the antitumor activity against MDA-MB-231 and MCF-7 human breast and cisplatin-resistant HCT-116 human colon cancer cell lines for compounds a-d, (ii) the cellular accumulation of the palladium compounds $b$ and $e$, (iii) the interaction of compounds $a-d$ with the pBluescript SK + plasmid DNA, (iv) the interaction of compounds $2 b$ and $2 d$ with the pBluescript SK + plasmid DNA in the presence of topoisomerase I, and (v) the cathepsin B inhibition test for the most cytotoxic palladium compounds a-d. The cytotoxicity of compound $3 \mathrm{e}$, one of the most antiproliferative complexes, was also studied toward the human umbilical vein endothelial cells (HUVEC) in quiescent and normal culture conditions. It should be noted that these cells in quiescent conditions are used as a model for nonproliferative normal cells. These analyses are compared with those previously reported by our group for palladium compounds e and for the platinum compound 4f.19,20

The aim of these studies is to establish structure-activity relationships upon the structure of the proposed compounds and their anticancer activity and the identification of plausible primary target biomolecules for them. 


\section{RESULTS AND DISCUSSION}

\section{Synthesis and Characterization of the Compounds.}

The structural formula and the numbering of the compounds under study are given in Scheme 1 . Benzophenone imines a-d were prepared by a condensation reaction between benzophenone and the corresponding amine using TiCl4 as Lewis acid promoter and drying agent in a molar ratio of 1:1:5 $\mathrm{TiCl}$ /benzophenone/amine by an adaptation of a previously reported method.21 Imines a-d were obtained in moderate to high yield and were characterized by EM, IR, and $1 \mathrm{H}$ and $13 \mathrm{C}\{1 \mathrm{H}\} \mathrm{NMR}$. Imine e $(\mathrm{Ph} 2 \mathrm{C}=\mathrm{NH})$ was available commercially and was used as received. Compounds $1 \mathrm{e}-4 \mathrm{e}$ and $4 \mathrm{f}$ were prepared according to the procedures previously described in our research group.19,20 Thus, treatment of imine e $(\mathrm{Ph} 2 \mathrm{C}=\mathrm{NH})$ with $\mathrm{Pd}(\mathrm{OAc}) 2$ in a 1:1 molar ratio in acetic acid at $60{ }^{\circ} \mathrm{C}$ for $24 \mathrm{~h}$ generated the dinuclear cyclopalladated compound 1e with acetato bridging ligands in high yield. A subsequent metathesis reaction of compound $1 \mathrm{e}$ with $\mathrm{LiCl}$ in acetone at room temperature produced the dinuclear cyclopalladated compound $2 \mathrm{e}$ with chlorido bridging ligands. The mononuclear compounds $3 \mathrm{e}$ and $4 \mathrm{e}$ were obtained by bridge-splitting reactions of the dinuclear compounds $1 \mathrm{e}$ and $2 \mathrm{e}$ with $\mathrm{PPh} 3$ in acetone at room temperature. Mixture A, the precursor of compound $4 \mathrm{f}$, was prepared by reaction of cis-[PtCl2(DMSO)2] and $\mathrm{NaOAc}$ in a 1:1 molar ratio with an excess of benzophenone imine in dry methanol under nitrogen and at reflux for $24 \mathrm{~h}$. A subsequent reaction of mixture A with $\mathrm{PPh} 3$ yielded compound $4 \mathrm{f}$. The purity of compounds $1 \mathrm{e}-4 \mathrm{e}$ and $4 \mathrm{f}$ was checked by IR and $1 \mathrm{H}$ NMR, and purity of compounds $3 \mathrm{e}, 4 \mathrm{e}$, and $4 \mathrm{f}$ was checked in addition by $31 \mathrm{P}\{1 \mathrm{H}\} \mathrm{NMR}$.

Compounds 1-4 from series a-d were obtained by an adaptation of the procedures given above for compounds $1 \mathrm{e}-4 \mathrm{e}$. It should be noted that the synthesis of compounds $2 \mathrm{a}, 2 \mathrm{c}$, and $4 \mathrm{c}$ was previously claimed,22,23 but their detailed preparative method and their characterization data were not reported, except for the $\mathrm{C}, \mathrm{H}$, and $\mathrm{N}$ elemental analyses of $2 \mathrm{a} .23$ According to the literature, 24 we propose an endo fivemembered ortho-cyclopalladated structure for the palladium compounds $a-d$. The endo descriptor denotes that the $\mathrm{C}=\mathrm{N}$ bond is included in the metalacycle. 25 This assumption was established unambiguously by the XRD molecular crystal structure determination of $1 \mathrm{a} \cdot 2 \mathrm{MeOH}, 1 \mathrm{c}, 1 \mathrm{~d}, 4 \mathrm{a}$, $4 \mathrm{~b} \cdot \mathrm{MeOH}$, and $4 \mathrm{c} \cdot \mathrm{MeOH}$ (see below). Compounds 1-4 from series a-d afforded satisfactory EM, IR, and $1 \mathrm{H}$ NMR. In addition, the $31 \mathrm{P}\{1 \mathrm{H}\}$ NMR spectra of compounds 3 and 4 from series a-d were also consistent with their proposed structure. 26

Details of the preparative method and isolation in pure form of the benzophenone imines a-d and their cyclopalladated derivatives 1-4 and selected characterization data for these compounds are given in the Supporting Information.

\section{XRD Molecular Structures of 1a, 1c, 1d, 4a, 4b, and 4c.}

Figures 2-7 show ball-and-stick models of the molecular structure of 1a, 1c, 1d, 4a, 4b, and 4c determined by singlecrystal X-ray diffraction analysis. Single crystals of $1 \mathrm{a} \cdot 2 \mathrm{MeOH}, 1 \mathrm{c}, 1 \mathrm{~d}, 4 \mathrm{a}$, $4 \mathrm{~b} \cdot \mathrm{MeOH}$, and $4 \mathrm{c} \cdot \mathrm{MeOH}$ were grown by slow evaporation of the solvents of a solution of the corresponding compound 1 in $\mathrm{CH} 2 \mathrm{Cl} 2, \mathrm{MeOH}$, and acetone in 1:1:1 volume ratio or by the slow evaporation of the solvents of a solution of the corresponding compound 4 in $\mathrm{CH} 2 \mathrm{Cl} 2$ and $\mathrm{MeOH}$ in a volume ratio of 1:1. The crystal structure reports and CIF files for these X-ray molecular crystal structure determinations are given in the Supporting Information. These structures have been also deposited in the Cambridge Crystallographic Data Centre with the following deposition numbers: 1025622 (4b $\mathrm{MeOH}), 1025623$ (1c), 1025624 (1d), $1025625(1 \mathrm{a} \cdot 2 \mathrm{MeOH}), 1025626(4 \mathrm{a})$, and $1025627(4 \mathrm{c} \cdot \mathrm{MeOH})$.

These molecular structures confirm the proposed structural formula for the compounds under study. Thus, all these molecules can be classified as endo five-membered orthocyclopalladated benzophenone imines. In addition, molecules $1 \mathrm{a}, 1 \mathrm{c}$, and $1 \mathrm{~d}$ are dinuclear with the acetato ligands bridging two 
cyclopalladated units and present a trans-folded structure, and molecules $4 \mathrm{a}, 4 \mathrm{~b}$, and $4 \mathrm{c}$ are mononuclear and present a trans-N,P configuration.

In the crystal of compound $1 \mathrm{~d}$, both halves of the molecules were equivalent because these molecules were situated over crystallographic binary proper rotation axes, but in the crystals of $1 \mathrm{a} \cdot 2 \mathrm{MeOH}$ and $1 \mathrm{c}$, the molecules of compounds $1 \mathrm{a}$ and $1 \mathrm{c}$ presented two nonequivalent halves, which differed between them in small differences in distances, angles, and torsion angles.

Distances and angles around of the palladium(II) centers for all these molecules were between the normal intervals.26-29 The chelate bite angles were those from the coordination sphere of the palladium(II) centers with the largest deviations from the ideal angles of 90 and $180^{\circ}$ and were $80.77(9)$ and $81.27(9)^{\circ}$ for $1 \mathrm{a}, 81.66(14)$ and $81.26(13)^{\circ}$ for $1 \mathrm{c}, 81.19(14)^{\circ}$ for $1 \mathrm{~d}, 80.70(8) \AA$ for $4 \mathrm{a}, 81.11(7)^{\circ}$ for $4 \mathrm{~b}$, and 80.69(7) $\AA$ for $4 \mathrm{c}$. The five-membered metalacycles in all these molecules were planar, and maximum deviated atoms from the five-membered planar metalacycles were $\mathrm{C} 10.064 \AA$ and $\mathrm{C} 21-0.78$ $\AA$ for 1a, C39-0.011(3) $\AA$ and N1 0.068(3) for 1c, C6 0.008(4) $\AA$ and C1 -0.008(4) for 1d, N1 -0.038(2) for $4 \mathrm{a}, \mathrm{N} 10.021(2)$ for $4 \mathrm{~b}$, and N1 $0.049 \AA$ for $4 \mathrm{c}$.

In compounds $1, \mathrm{Pd}-\mathrm{O}$ bonds trans to the metalated carbon atoms were longer than $\mathrm{Pd}-\mathrm{O}$ bonds trans to the iminic nitrogen atom [Pd1-O1 2.1247(16) $\AA$ and $\mathrm{Pd} 2-\mathrm{O} 32.1573(16) \AA$ but $\mathrm{Pd} 1-\mathrm{O} 42.0576(17)$ $\AA$ and $\mathrm{Pd} 2-\mathrm{O} 22$ 2.0374(16) $\AA$ for 1a, Pd1-O2 2.155(2) $\AA$ and Pd2-O3 2.147(3) $\AA$ but $\mathrm{Pd} 1-\mathrm{O} 42.055(2)$ and Pd2-O1 2.042(2) $\AA$ for 1c, and Pd1-O1 2.141(3) but Pd1-O2 2.050(3) $\AA$ for 1d]. These results were in agreement with the greater trans influence of the palladated carbon atom in relation to the iminic nitrogen atom.30 Also, the greater trans influence of the phosphorus atom of $\mathrm{PPh} 3$ in relation to the oxygen atom of the acetate ligand explained the longer $\mathrm{Pd}-\mathrm{N}$ bonds in compounds 4 in relation to compounds 1 [Pd1-N1 2.1028(19) $\AA$ for 4a, Pd1-N1 2.1162(17) $\AA$ for 4b, Pd1-N1 2.0964(14) $\AA$ for 4c but Pd1-N1 2.0191(19) $\AA$ and Pd2-N2 2.0177(19) $\AA$ for 1a, Pd1-N2 2.010(3) $\AA$ and Pd2-N1 2.022(3) $\AA$ for 1c, and Pd1-N1 2.038(3) $\AA$ for $1 \mathrm{~d}] .30$

The angle between the palladacycles in compounds $1 \mathrm{a}, 1 \mathrm{c}$, and $1 \mathrm{~d}$ were $25.11,27.66(14)$, and $54.16^{\circ}$, respectively, and the distances between palladium atoms were 2.90693(3), 2.8698(4), and $3.204 \AA$, respectively. These distances were too long to be considered a palladium-palladium single bond.31

The angles between the palladacycles and the phenyls bonded to the methinic carbon atoms in these molecules were 59.38 and $58.78^{\circ}$ for $1 \mathrm{a}, 78.4(2)$ and $62.42(18)^{\circ}$ for $1 \mathrm{c}, 86.1(2)^{\circ}$ for $1 \mathrm{~d}, 85.11(11)^{\circ}$ for $4 \mathrm{a}, 66.69(12)^{\circ}$ for $4 \mathrm{~b}$, and $76.75^{\circ}$ for $4 \mathrm{c}$. In compounds $1 \mathrm{a}$ and $4 \mathrm{a}$, the angles between the phenyls bonded to the iminic nitrogen atoms and the palladacycles were 61.57 and $61.24^{\circ}$ for $1 \mathrm{a}$ and $79.75(11)^{\circ}$ for $4 \mathrm{a}$, and the angle between the 1-naphthyl group bonded to the iminic nitrogen atom and the palladacycle was $75.23(10)^{\circ}$ in compound $4 \mathrm{~b}$.

Finally, in all these molecules, the metalated phenyl and the metalacycle were almost coplanar, with the angles between them being 7.05 and $5.82^{\circ}$ for $1 \mathrm{a}, 1.73(16)$ and $7.23(15)^{\circ}$ for $1 \mathrm{c}, 4.15(18)^{\circ}$ for $1 \mathrm{~d}$, $5.50(11)^{\circ}$ for $4 \mathrm{a}, 1.00(10)^{\circ}$ for $4 \mathrm{~b}$, and $4.52^{\circ}$ for $4 \mathrm{c}$.

Biological Studies. Antiproliferative Activity. The cytotoxicity of palladium compounds a-d against MDA-MB-231 and MCF-7 breast and cisplatin-resistant HCT-116 colon adenocarcinoma human cell lines was studied, and their IC50 values against the precedent cell lines are collected in Table 1. For comparison, the IC50 values against the above cited cell lines for cisplatin, free imines, palladium compounds e, and platinum compound $4 \mathrm{f}$ are also included in Table 1 . It should be noted that the IC50 values for palladium compounds e and compound $4 \mathrm{f}$ against the cancer cell lines cited above have been previously reported by our research group.19,20 Table 1 gives also the clog $\mathrm{P}$ for the compounds under study. This is the calculated logarithmic value of the n-octanol/water partition coefficient of the compound under consideration and can be related to its lipophilicity. 32 
For a better understanding of Table 1, we have included a color code for the cells. Thus, green ones mean that the compounds under consideration are more cytotoxic than cisplatin against the specified tumor cell lines; yellow ones are compounds that are cytotoxic but less cytotoxic than cisplatin; red ones are compounds that are not cytotoxic with IC50 values greater than $100 \mu \mathrm{M}$, and cells not filled with color indicate compounds that are poorly cytotoxic (IC50 $>50 \mu \mathrm{M})$ or noncytotoxic. Cells corresponding to cisplatin are filled with blue color.

From data given in Table 1, the following trend for the in vitro antitumor activity of compounds 1-4 from series a-e and compound $4 \mathrm{f}$ can be derived: $3 \mathrm{e} \approx 4 \mathrm{e}$ (more cytotoxic than cisplatin) $>4 \mathrm{f}$ (more cytotoxic than cisplatin) $>2 \mathrm{e} \approx 1 \mathrm{e}$ (less cytotoxic than cisplatin) $>2 \mathrm{~d} \approx 2 \mathrm{c} \approx 2 \mathrm{a}$ (less cytotoxic than cisplatin) $>3 \mathrm{a}$ (less cytotoxic than cisplatin) $>$ the other compounds (inactive or poorly active).

This trend seems to indicate that an accurate balance between hydrophilicity and lipophilicity could be regulating the in vitro antitumor activity of these cyclometalated benzophenone imines. For instance, for palladium compounds e, which should be the most hydrophilic ones due to the presence of the $\mathrm{N}-\mathrm{H}$ function in their structural formula, when passing from $3 \mathrm{e}$ and $4 \mathrm{e}$ to $1 \mathrm{e}$ and $2 \mathrm{e}$, a substantial drop in activity is observed. This should be ascribed to the decrease in lipophilicity on going from $3 \mathrm{e}$ and $4 \mathrm{e}$ to 1e and $2 \mathrm{e}$ (see clog P values in Table 1). On the other hand, for palladium compounds a, c, and d, which are more lipophilic than palladium compounds e, since in this series the group bonded to the iminic nitrogen is phenyl, benzyl, or $\alpha$-methylbenzyl, respectively, the maximum activity corresponds to compounds $2 \mathrm{a}, 2 \mathrm{c}$, and $2 \mathrm{~d}$, which are the ones with the lowest lipophilicity of these series (see clog P values in Table 1). Finally, compound $2 b$ is not active at all since this compound is more lipophilic ( $R$ $=1$-naphthyl) than compounds $2 \mathrm{a}(\mathrm{R}=$ phenyl $), 2 \mathrm{c}(\mathrm{R}=$ benzyl $)$, and $2 \mathrm{~d}(\mathrm{R}=\alpha$-methylbenzyl $)$. At present, we cannot find a reliable explanation for the IC50 value of compound $3 \mathrm{a}(12 \mu \mathrm{M})$ toward the MDA-MB-231 cell line. In addition, the great cytotoxicity observed for palladium compounds e could also be related to their better solubility and/or to the ability of their NH moiety to establish hydrogen bonds with a target biomolecule. 33

It should be noted that water solubility for the organometallic compounds under study is in fact very low, but we expect that, once in solution in the biological media, palladium compounds a- $d$ should be converted into the ionic aqua complexes $[\mathrm{Pd}(\mathrm{C}, \mathrm{N})(\mathrm{H} 2 \mathrm{O}) 2] \mathrm{X}(\mathrm{X}=\mathrm{OAc}$ or $\mathrm{Cl})$ (compounds I) and trans$\mathrm{N}, \mathrm{P}-[\mathrm{Pd}(\mathrm{C}, \mathrm{N})(\mathrm{PPh} 3)(\mathrm{H} 2 \mathrm{O})] \mathrm{X}(\mathrm{X}=\mathrm{OAc}$ or $\mathrm{Cl})$ (compounds II) by substitution of their chlorido ligands by water molecules. Therefore, we propose that the responsible species for the biological activities studied here are the ionic aqua complexes I and II commented above. Similar aqua complexes were proposed to be the responsible species for the biological activities observed for palladium compound e and compound 4f.19,20

The cytotoxicity of compound 3e, one of the most potent complexes in the cancer cell lines evaluated, and cisplatin was also tested against HUVEC cells in starving culture conditions, in which cells are almost quiescent or in low proliferative conditions, and in normal cell culture conditions, in which cells are in highly proliferative conditions (see Experimental Section for the details). Table 2 gives the IC50 values for these studies. Interestingly, compound $3 \mathrm{e}$ was 2 times and 1.5 times less cytotoxic than cisplatin toward the HUVEC cells in starving and in normal cell culture conditions, respectively.

Cell Accumulation. The cellular accumulation of platinum drugs in vivo is well-documented, and it is believed to be dependent on both passive diffusion and active transport. Active transport can involve the entry into the cell with the help of copper transporters and organic cation transporters, as well as active efflux of the drug by copper efflux transporters. 34 The relationship between lipophilicity, cellular accumulation, and cytotoxicity of oxaliplatin derivatives with different substituents at the 4 position of the cyclohexane ring has been investigated. In this study, the more lipophilic compounds revealed a lower cytotoxicity, although the early influx rate (passive diffusion) was increased in the case of more lipophilic platinum complexes. Alterations in the reactivity in the intracellular environment of the platinum compounds with bulky substituents or increased sequestration of the most lipophilic platinum 
complexes in cellular organelles such as lysosomes could be responsible for their reduced cytotoxicity in the investigated cell lines.35 This explanation could account for the lower cytotoxicity observed for palladium compounds $a-d$ with regard to that of palladium compounds $e$ and the absence of antiproliferative activity of palladium compounds $b$, which present the bulkier and more lipophilic substituent in series a-d.

To get more insight on the antitumor activity of the benzophenone cyclopalladated imines, the cellular accumulation of palladium compounds $b$ and e was studied and compared with that of cisplatin. In these studies, palladium was used as a measure of the cellular accumulation of the palladium compounds, and platinum was used as a measure of the cellular accumulation of cisplatin. Mole of palladium or platinum per cell was determined by ICP-MS. Table 3 gives the cellular accumulation for the tested compounds and for cisplatin after $4 \mathrm{~h}$ of incubation on the breast cancer cell line MDA-MB-231.

The accumulation of the tested compounds in the cell line studied was considerably greater than that of cisplatin, and compounds $3 \mathrm{e}$ and $4 \mathrm{e}$, which are the compounds with the highest antitumor activity against the MDA-MB-231 cell line, were those with the highest amounts of palladium accumulated per cell. The accumulation of these latter compounds was about 50 and 100 times higher than that of cisplatin. Interestingly, the noncytotoxic compounds $1 \mathrm{~b}-4 \mathrm{~b}$ were accumulated on the MDA-MB-231 cell line in quite high amounts. This result suggests that these compounds could be noncytotoxic because of their bulky 1-naphthyl group, which should render their palladium(II) centers less reactive, or because of their accumulation in cellular organelles such as lysosomes due to their elevated lipophilicity.35

DNA Interaction. The binding of palladium compounds a-d to DNA was studied by their ability to modify the electrophoretic mobility of the supercoiled closed circular (ccc) and the open circular (oc) forms of pBluescript SK + plasmid DNA.

Figure 8 shows the electrophoretic mobility of pBluescript SK + plasmid DNA incubated with the free ligands $\mathrm{a}-\mathrm{d}$ and palladium compounds $\mathrm{a}-\mathrm{d}$ at increasing concentrations. To provide a basis for comparison, incubation of DNA with cisplatin and ethidium bromide (EB) was also performed using the same concentrations and conditions. The electrophoretic mobility of pBluescript SK + plasmid DNA incubated with palladium compounds e and compound $4 \mathrm{f}$ was previously reported by our research group and has also been included in Figure 8 for a comparative purpose.19,20

As expected, cisplatin greatly altered the electrophoretic mobility of pBluescript SK + plasmid DNA at $2.5 \mu \mathrm{M}$, but for EB, only a very slight decrease in the electrophoretic mobility of DNA was detected between 25 and $100 \mu \mathrm{M} .19$ For the free ligands $\mathrm{a}-\mathrm{d}$, no shift in the rate of migration of the supercoiled band was observed.

Palladium compounds a-e were less efficient than cisplatin in removing the supercoils from DNA, in spite of the fact that some were more cytotoxic than cisplatin. Only compound $3 \mathrm{~b}$ produced at $10 \mu \mathrm{M}$ concentration (lane 4), a significant effect on the mobility of pBluescript DNA. At $25 \mu \mathrm{M}$ concentration (lane 5), complexes $1 \mathrm{a}-1 \mathrm{c}$ induced significant changes in plasmid DNA mobility. Complexes $1 \mathrm{a}-1 \mathrm{e}$, $2 \mathrm{e}$, and $3 \mathrm{a}-3 \mathrm{~d}$ showed the same effect of coalescence and positive supercoiling observed for cisplatin but at a higher concentration. Compound $4 \mathrm{f}$ was also less efficient than cisplatin for removing the supercoils from pBluescript SK + plasmid DNA, suggesting that the unwinding of the DNA is not the key factor responsible for its cytotoxicity. 20

Compounds with the greatest effect on DNA mobility did not necessarily correlate to those with the lowest IC50 values. For instance, modifications induced on DNA mobility for 1a were greater than those produced for $2 \mathrm{a}$, but $2 \mathrm{a}$ was more potent than $1 \mathrm{a}$ in the three cancer cell lines assayed. On the other hand, noncytotoxic cyclopalladated compounds (i.e., $1 \mathrm{~b}$ and $3 \mathrm{~b}$, IC50 values $>100 \mu \mathrm{M}$ ) induced significant changes on DNA mobility. It is hypothesized that, in the conditions of the gel mobility assay, compounds such as $1 \mathrm{~b}, 3 \mathrm{~b}$, or $4 \mathrm{f}$ interacted with DNA in a similar way as that of cisplatin but at a higher concentration. 
288 To evaluate the ability of the investigated complexes to intercalate into DNA, a topoisomerase-based 289 gel assay was performed on $2 \mathrm{~b}$ and $2 \mathrm{~d}$. Supercoiled pBluescript plasmid DNA was incubated in the 290 presence of topoisomerase I at increasing concentrations of compounds $2 \mathrm{a}$ and $2 \mathrm{~b}$. The results are given 291 in Figure 9, and they show that $2 \mathrm{~b}$ and $2 \mathrm{~d}$ do not prevent unwinding of DNA by the action of

292

293

294

295

296

297

298

299

300

301

302

303

304

305

306

307

308

309

310

311

312

313 topoisomerase I, indicating that these compounds are neither intercalators nor inhibitors of topoisomerase I.8

The precedent results suggest that DNA is not a primary target biomolecule for the cyclopalladated and cycloplatinated benzophenone imines under study.

Cathepsin B Inhibition. Cathepsin B is a cysteine metalloprotease highly upregulated in a wide variety of cancers by mechanisms ranging from gene amplification to post-transcriptional modification. The exact role of cathepsin B in solid tumors has yet to be defined, but it has been proposed to participate in metastasis, angiogenesis, and tumor progression. Recently, compounds based on palladium, platinum, ruthenium, rhenium, gold, and tellurium were shown to be effective inhibitors of cathepsin B.36 In addition, an excellent correlation between cathepsin B inhibition and cytotoxicity for some dinuclear biphosphane palladacycles 37 and mononuclear platinacycles containing a fluorinated phosphane 38 has been reported. In spite of these results, we have recently reported 20 that compounds $1 \mathrm{e}-4 \mathrm{e}$ and $4 \mathrm{f}$ are not efficient inhibitors of cathepsin B although they are quite cytotoxic in vitro.

Following these studies, we have determined the cathepsin B inhibition activity for compounds $2 \mathrm{a}, 2 \mathrm{c}$, $2 \mathrm{~d}$, and $3 \mathrm{a}$, which are the more active ones from series $\mathrm{a}-\mathrm{d}$ in relation to their in vitro antitumor activity. The results are given in Table 4 . This table also includes our previously reported results for the cathepsin $\mathrm{B}$ inhibition test for palladium compounds e and compound $4 \mathrm{f}$ for a comparative purpose. 20

Compounds $2 \mathrm{a}, 2 \mathrm{c}, 2 \mathrm{~d}$, and $3 \mathrm{a}$ inhibited cathepsin $\mathrm{B}$ in a dose-dependent manner, but they were not efficient as cathepsin B inhibitors since $50 \%$ of residual activity of the enzyme is not observed until quite high concentrations, greater than 50 or $100 \mu \mathrm{M}$ depending on the compound. These results confirm that cathepsin B is not a primary target biomolecule for the cyclopalladated and cycloplatinated benzophenone imines studied here. 


\section{CONCLUSIONS}

317 The present study and previous ones 19,20 confirm that compounds $3 \mathrm{e}, 4 \mathrm{e}$, and $4 \mathrm{f}$ are the most active in 318 vitro antitumor agents against the evaluated cell lines between a quite large number of cyclometalated 319 benzophenone imines studied. Compounds $3 \mathrm{e}$ and $4 \mathrm{e}$ were about 4 times more active than cisplatin 320 against the MDA-MB-231 and MCF-7 breast human cancer lines, and compound $4 \mathrm{f}$ is about 4 times more active than cisplatin against the cisplatin-resistant HCT-116 colon human cancer cell line. The in vitro cytotoxicity of the cyclopalladated benzophenone imines a-e against the studied cancer cell lines seems to be regulated by an adequate balance between their hydrophilicity and lipophilicity. In addition, accumulation of palladium compounds $e$ and $b$ in the MDAMB-231 cell line was considerably greater than that of cisplatin, but palladium compounds $b$ were noncytotoxic. Furthermore, compound 3e, one of the most potent complexes in the cell lines evaluated, was 3 times and 1.5 times less cytotoxic than cisplatin toward HUVEC cells in starving (quiescent) and normal cell culture conditions, respectively. Concerning the determination of plausible primary target biomolecules for these cyclopalladated and cycloplatinated benzophenone imines, DNA migration studies and cathepsin B inhibition tests suggest that these biomolecules are not their primary target biomolecules. 


\section{EXPERIMENTAL SECTION}

Cell Culture. Colon HCT-116 and breast cancer MCF-7 and MBA-MD-231 cells were grown as a monolayer culture in minimum essential medium (DMEM with L-glutamine, without glucose and without sodium pyruvate) in the presence of $10 \%$ heat-inactivated fetal calf serum (FCS), $10 \mathrm{mM}$ Dglucose, and $0.1 \%$ streptomycin/penicillin, in standard culture conditions (humidified air with $5 \% \mathrm{CO} 2$ at $37^{\circ} \mathrm{C}$ ).

Cell Viability Assay for HC-T116, MDA-MB-231, and MCF-7Cell Lines. A stock solution (50 mM) of each compound was prepared in high-purity DMSO. Then, serial dilutions were made with DMSO/DMEM (1:1), and finally a 1:500 dilution on culture medium was prepared. Final assay concentration of DMSO was the same in all experiments and was $0.2 \%$. The assay was performed as described.39 HCT-116, MDA-MB-231, and MCF-7 cells were plated at 5000 cells/well in $100 \mu \mathrm{L}$ of media in tissue culture 96-well plates. After $24 \mathrm{~h}$, medium was replaced by $100 \mu \mathrm{L} /$ well of drug serial dilutions. Control wells did not contain the compounds under study. Each point concentration was run in triplicate. Reagent blanks, containing media and colorimetric reagent without cells, were run on each plate. Blank values were subtracted from test values and were routinely $5-10 \%$ of the control values. Plates were incubated $72 \mathrm{~h}$. Hexosaminidase activity was measured according to the following protocol. The medium was removed, and cells were washed once with PBS. Sixty microliters of substrate solution of $7.5 \mathrm{mM}$ p-nitrophenol-N-acetyl- $\beta$-D-glucosamide, $0.1 \mathrm{M}$ sodium citrate at $\mathrm{pH} 5.0$, and $0.25 \%$ Triton $\mathrm{X}-100$ was added to each well and incubated at $37{ }^{\circ} \mathrm{C}$ for $1-2 \mathrm{~h}$. After this incubation time, a bright yellow color appeared. Then, the plates were developed by adding $90 \mu \mathrm{L}$ of developer solution $(50 \mathrm{mM}$ glycine, $\mathrm{pH}$ 10.4; $5 \mathrm{Mm}$ EDTA), and the absorbance was recorded at 410nm.

Cell Viability Assay for the HUVEC Cells. Cytotoxicity in normal cells was assayed using primary human umbilical vein endothelial cells, at passage 6-8. Viability was assayed in two culture conditions: highly proliferative, where $10 \%$ of FCS, supplements, and growth factors were included in culture media; low proliferative, where cells were almost quiescent, by restraining FCS at 2\% with no supplements or growth factors. Assays were done as described for tumor cell lines, plating $5000 \mathrm{cell} / \mathrm{well}$ for each growing condition.

Cell Accumulation. Cell accumulation of compounds was measured in the MDA-MB-231 cell line. A total of $1 \times 106$ cells was seeded in $6 \mathrm{~mm}$ tissue culture dishes for $16 \mathrm{~h}$ in DMEM/high glucose plus $10 \%$ FCS. Then, compounds were added at $50 \mu \mathrm{M}$ for $4 \mathrm{~h}$ at $37{ }^{\circ} \mathrm{C}, 5 \% \mathrm{CO}$. Cisplatin was used as a positive control at the same concentration and DMSO as a vehicle control. After treatment, cells were washed twice with PBS, tripsinized, and harvested in PBS. Cell suspension was centrifuged, and pellets were digested with $12 \mathrm{M} \mathrm{HCl}$ and diluted to $1.2 \mathrm{M} \mathrm{HCl}$. Each treatment was done in duplicate. The samples were analyzed by ICP-MS.

DNA Migration Studies. A stock solution $(10 \mathrm{mM})$ of each compound was prepared in high-purity DMSO. Then, serial dilutions were made in Milli-Q water $(1: 1)$. Plasmid pBluescript SK+ was obtained using a kit as described by the manufacturer. Interaction of drugs with pBluescript SK + plasmid DNA was analyzed by agarose gel electrophoresis following a modification of the method previously described.40 Plasmid DNA aliquots $(40 \mu \mathrm{g} \mathrm{mL}-1)$ were incubated in TE buffer $(10 \mathrm{mM}$ Tris-HCl, 1 mM EDTA, pH 7.5) with different concentrations of test compounds ranging from 0 to $200 \mu \mathrm{M}$ at $37^{\circ} \mathrm{C}$ for $24 \mathrm{~h}$. Final DMSO concentration in the reactions was always lower than $1 \%$. For comparison, cisplatin and ethidium bromide were used as reference controls. Aliquots of $20 \mu \mathrm{L}$ of the incubated solutions of compounds containing $0.8 \mu \mathrm{g}$ of DNA were subjected to $1 \%$ agarose gel electrophoresis in TAE buffer (40 mM Tris-acetate, $2 \mathrm{mM}$ EDTA, $\mathrm{pH} 8.0$ ). The gel was stained in TAE buffer containing EB $(0.5 \mathrm{mg} \mathrm{mL}-1)$ and visualized and photographed under UV light. 
378 Topoisomerase I-based experiments were performed as described previously.41 Supercoiled 379 pBluescript DNA, obtained as described above, was treated with topoisomerase I in the absence or 380 presence of increasing concentrations of compounds $2 \mathrm{~b}$ and $2 \mathrm{~d}$. Assay mixtures contained supercoiled pBluescript DNA $(0.8 \mu \mathrm{g})$, calf thymus topoisomerase I ( 3 units), and complexes $2 \mathrm{~b}$ and $2 \mathrm{~d}(0-100 \mu \mathrm{M})$ in $20 \mu \mathrm{L}$ of Tris- $\mathrm{HCl}$ buffer (pH 7.5) containing $175 \mathrm{mM} \mathrm{KCl}, 5 \mathrm{mM} \mathrm{MgCl} 2$, and $0.1 \mathrm{mM}$ EDTA. Ethidium bromide $(10 \mu \mathrm{M})$ was used as a control of intercalating agents and etoposide $(100 \mu \mathrm{M})$ as a control of the nonintercalating agent. Reactions were incubated for $30 \mathrm{~min}$ at $37^{\circ} \mathrm{C}$ and stopped by the addition of $2 \mu \mathrm{L}$ of agarose gel loading buffer. Samples were then subjected to electrophoresis, and DNA bands were stained with ethidium bromide as described above.

Cathepsin B Inhibition Assay. The colorimetric cathepsin B assay was performed as described by Casini et al.42 with few modifications. Briefly, the reaction mixture contained $100 \mathrm{mM}$ sodium phosphate (pH 6.0), $1 \mathrm{mM}$ EDTA, and $200 \mu \mathrm{M}$ sodium Ncarbobenzoxy-L-lysine p-nitrophenyl ester as substrate. To have the enzyme catalytically active before each experiment, the active site of the cysteine was reduced by treatment with dithiothreitol (DTT). For this purpose, $5 \mathrm{mM}$ DTT was added to the cathepsin B sample, before dilution, and incubated $1 \mathrm{~h}$ at $30^{\circ} \mathrm{C}$. To test the inhibitory effect of the palladium compounds on cathepsin $\mathrm{B}$, activity measurements were performed in triplicate using fixed concentrations of enzyme $(500 \mathrm{nM})$ and substrate $(200 \mu \mathrm{M})$. The palladium compounds were used at concentrations ranging from 50 to $100 \mu \mathrm{M}$. Previous to the addition of substrate, cathepsin B was incubated with the different compounds at $25^{\circ} \mathrm{C}$ for $2 \mathrm{~h}$. The cysteine proteinase inhibitor E- 64 was used as a positive control of cathepsin B inhibition. Complete inhibition was achieved at $10 \mu \mathrm{M}$ concentration of E-64. Activity was measured over $1.5 \mathrm{~min}$ at $326 \mathrm{~nm}$ on a UV spectrophotometer. 
400 AUTHOR INFORMATION

401

402 Corresponding Author

403 *Tel.: +34 93 4039131. E-mail: joan.albert@qi.ub.es.

404 
405 ACKNOWLEDGEMENTS

406

407 Financial support from project CTQ2009-11501/BQU from the Spanish Ministerio de Ciencia e 408 Innovación and Grant 2009-SGR-1111 from Generalitat de Catalunya is acknowledged. R.Q. 409 acknowledges MAEC-AECID for a master scholarship.

410 
411

412

413

414

415

416

417

418

419

420

421

422

423

424

425

426

427

428

429

430

431

432

433

434

435

436

437

438

439

440

441

442

443

444

445

446

447

\section{References}

(1) Caires, A. C. F. Anti-Cancer Agents Med. Chem. 2007, 7, 484-491.

(2) Abu-Surrah, A. S.; Al-Sa'doni, H. H.; Abdalla, M. Y. Cancer Ther. 2008, 6, 1-10.

(3) Reedijk, J. Platinum Met. Rev. 2008, 52, 2-11.

(4) Omae, I. Coord. Chem. Rev. 2014, 280, 84-95.

(5) Cutillas, N.; Yellol, G. S.; de Haro, C.; Vicente, C.; Rodríguez, V.; Ruiz, J. Coord. Chem. Rev. 2013, 257, 2784-2797.

(6) Quiroga, A. G.; Navarro-Ranninger, C. Coord. Chem. Rev. 2004, 248, 119-133.

(7) Albert, J.; Bosque, R.; Crespo, M.; García, G.; Granell, J.; López, C.; Lovelle, M. V.; Qadir, R.; González, A.; Jayaraman, A.; Mila, E.; Cortés, R.; Quirante, J.; Calvis, C.; Messeguer, R.; Badía, J.; Baldomà, L.; Cascante, M. Eur. J. Med. Chem. 2014, 84, 530-536.

(8) Albert, J.; Bosque, R.; Cadena, M.; D’Andrea, L.; Granell, J.; González, A.; Quirante, J.; Calvis, C.; Messeguer, R.; Badía, J.; Baldoma, L.; Calvet, T.; Font-Bardia, M. Organometallics 2014, $33,2862-2873$.

(9) Aliwaini, S.; Swarts, A. J.; Blanckenberg, A.; Mapolie, S.; Prince, S. Biochem. Pharmacol. 2013, 86, 1650-1663.

(10) Guimaraes-Correa, A. B.; Crawford, L. B.; Figueiredo, C. R.; Gimenes, K. P.; Pinto, L. A.; Rios Grassi, M. F.; Feuer, G.; Travassos, L. R.; Caires, A. C. F.; Rodrigues, E. G.; Marriott, S. J. Viruses 2011, 3, 1041-1058.

(11) Serrano, F. A.; Matsuo, A. L.; Monteforte, P. T.; Bechara, A.; Smaili, S. S.; Santana, D. P.; Rodrigues, T.; Pereira, F. V.; Silva, L. S.; Machado, J., Jr.; Santos, E. L.; Pesquero, J. B.; Martins, R. M.; Travassos, L. R.; Caires, A. C. F.; Rodrigues, E. G. BMC Cancer 2011, 11, 296.

(12) Santana, D. P.; Faria, P. A.; Paredes-Gamero, E. J.; Caires, A. C. F.; Nantes, I. L.; Rodrigues, T. Biochem. J. 2009, 417, 247-256.

(13) da Rocha, M. C.; Santana, A. M.; Ananias, S. R.; de Almeida, E. T.; Mauro, A. E.; Placeresa, M. C. P.; Carlos, I. Z. J. Braz. Chem. Soc. 2007, 18, 1473-1480.

(14) Barbosa, C. M. V.; Oliveira, C. R.; Nascimento, F. D.; Smith, M. C. M.; Fausto, D. M.; Soufen, M. A.; Sena, E.; Araújo, R. C.; Tersariol, I. L. S.; Bincoletto, C.; Caires, A. C. F. Eur. J. Pharmacol. 2006, 542, 37-47.

(15) Bincoletto, C.; Tersariol, I. L. S.; Oliveira, C. R.; Dreher, S.; Fausto, D. M.; Soufen, M. A.; Nascimento, F. D.; Caires, A. C. F. Bioorg. Med. Chem. 2005, 13, 3047-3055.

(16) Rodrigues, E. G.; Silva, L. S.; Fausto, D. M.; Hayashi, M. S.; Dreher, S.; Santos, E. L.; Pesquero, J. B.; Travassos, L. R.; Caires, A. C. F. Int. J. Cancer 2003, 107, 498-504.

(17) Hebeler-Barbosa, F.; Rodrigues, E. G.; Puccia, R.; Caires, A. C. F.; Travassos, L. R. Clin. Transl. Oncol. 2008, 1, 110-120.

(18) Caires, A. C. F.; Trindade, C. B.; Tersariol, I. L. S. Patent Appl. WO/2004/019924, 2014. 
(19) Albert, J.; García, S.; Granell, J.; Llorca, A.; Lovelle, M. V.; Moreno, V.; Presa, A.; Rodríguez, L.; Quirante, J.; Calvis, C.; Messeguer, R.; Badía, J.; Baldomà, L. J. Organomet. Chem. 2013, 724, 289-296.

(20) Albert, J.; D’Andrea, L.; Granell, J.; Pla-Vilanova, P.; Quirante, J.; Khosa, M. K.; Calvis, C.; Messeguer, R.; Badía, J.; Baldomà, L.; Font-Bardia, M.; Calvet, T. J. Inorg. Biochem. 2014, $140,80-88$.

(21) Dai, W.; Srinivasan, R.; Katzenellenbogen, J. A. J. Org. Chem. 1989, 54, 2204-2208.

(22) Clark, P. W.; Dyke, S. F.; Smith, G.; Kennard, C. H. L. J. Organomet. Chem. 1987, 330, 447-460.

(23) Onoue, H.; Moritani, I. J. Organomet. Chem. 1972, 43, 431-436.

(24) Albert, J.; Gómez, M.; Granell, J.; Sales, J.; Solans, X. Organometallics 1990, 9, 1405-1413.

(25) Albert, J.; D’Andrea, L.; Granell, J.; Tavera, R.; Font-Bardia, M. Solans, X. J. Organomet. Chem. 2007, 692, 3070-3080.

(26) Albert, J.; Bosque, R.; D’Andrea, L.; Granell, J.; Font-Bardia, M. Calvet, T. Eur. J. Inorg. Chem. 2011, 3617-3631.

(27) Albert, J.; Granell, J.; Sales, J.; Font-Bardía, M.; Solans, X. Organometallics 1995, 14, $1393-1404$

(28) Albert, J.; Ceder, R. M.; Gómez, M.; Granell, J.; Sales, J. Organometallics 1992, 11, 1536-1541.

(29) Ghedini, M.; Crispini, A. Comments Inorg. Chem. 1999, 21, 53-68.

(30) Appleton, T. G.; Clark, H. C.; Manzer, L. E. Coord. Chem. Rev. 1973, 10, 335-422.

(31) Murahashi, T.; Kurosawa, H. Coord. Chem. Rev. 2002, 231, 207-228.

(32) See for instance: Fetzer, L.; Boff, B.; Ali, M.; Xiangjun, M. Collin, J. P.; Sirlin, C.; Gaiddon, C.; Pfeffer, M. Dalton Trans. 2011, 40, 8869-8878.

(33) Ramos-Lima, F. J.; Moneo, V.; Quiroga, A. G.; Carnero, A.; Navarro-Ranninger, C. Eur. J. Med. Chem. 2010, 45, 134.

(34) Jung, Y.; Lippard, S. J. Chem. Rev. 2007, 107, 1387-1407.

(35) Bub, I.; Garmann, D.; Galanski, M.; Weber, G.; Kalayda, G. V.; Keppler, B. K.; Jaehde, U. J. Inorg. Biochem. 2011, 105, 709-717.

(36) Fricker, S. P. Metallomics 2010, 2, 366-377.

(37) Spencer, J.; Casini, A.; Zava, O.; Rathnam, R. P.; Velhanda, S. K.; Pfeffer, M.; Callear, S. K.; Hursthoused, M. B.; Dyson, P. J. Dalton Trans. 2009, 10731-10735.

(38) Cutillas, N.; Martínez, A.; Yellol, G. S.; Rodríguez, V.; Zamora, A.; Pedreño, M.; Donaire, A.; Janiak, Ch.; Ruiz, J. Inorg. Chem. 2013, 52, 13529-13535.

(39) Givens, K. T.; Kitada, S.; Chen, A. K.; Rothschiller, J.; Lee, D. A. Invest. Ophthalmol. Visual Sci. 1990, 31, 1856-1862.

(40) Abdullah, A.; Huq, F.; Chowdhury, A.; Tayyem, H.; Beale, P.; Fisher, K. BMC Chem. Biol. 2006, 6, 3 . 
485

486

487

488

489

490
(41) Sappal, D. S.; McClendon, A. K.; Fleming, J. A.; Thoroddsen, V.; Connolly, K.; Reimer, C.; Blackman, R. K.; Bulawa, C. E.; Osheroff, N.; Charlton, P.; Rudolph-Owen, L. A. Mol. Cancer Ther. 2004, 3, 47-58.

(42) Casini, A.; Gabbiani, C.; Sorrentino, F.; Rigobello, M. P.; Bindoli, A.; Geldbach, T. J.; Marrone, A.; Re, N.; Hartinger, C. G.; Dyson, P. J.; Messori, L. J. Med. Chem. 2008, 51, 6773-6781. 
491

492

493

494

495

496

497

498

499

500

501

502

503

504

505

506

507

508

509

510

511

512

513

514

515

516

517

518

519

520

521

522

523

524

525

526

527

528

529

530

531

\section{Legends to figures}

Figure 1. Structural formula of cyclopalladated compounds with chances of progressing for evaluation as drug candidates.

Figure 2. XRD molecular structure of compound 1a. Selected bond distances $(\AA)$ and angles (deg): Pd1-C9 1.950(2), Pd1-N1 2.0191(19), Pd1-O4 2.0576(17), Pd1-O1 2.1247(16), Pd1-Pd2 2.9069(3), Pd2-C2 1 1.943(2), Pd2-N2 2.0177(19), Pd2-O2 2.0374(16), Pd2-O3 2.1573(16), C9-Pd1-N1 80.77(9), C9-Pd1-O4 93.80(8), N1-Pd1-O4 173.36(7), C9-Pd1-O1 176.17(8), N1-Pd1-O1 95.47(7), O4-Pd1-O1 89.89(7), C21-Pd2-N2 81.27(9), C21-Pd2-O2 92.79(8), N2-Pd2-O2 173.53(7), C21-Pd2-O3 176.31(8), N2-Pd2-O3 95.15(7), O2-Pd2-O3 90.83(7).

Figure 3. XRD molecular structure of compound 1c. Selected bond distances $(\AA)$ and angles (deg): Pd1-C44 1.968(3), Pd2-C3 1.947(3), Pd1-O2 2.155(2), Pd2-O3 2.147(3), Pd1-N2 2.010(3), Pd2-N1 2.022(3), Pd1-O4 2.055(2), Pd2-O1 2.042(2), Pd1-Pd2 2.8698(4), O2-Pd1-C44 176.26(12), O3-Pd2-C3 176.91(12), O4-Pd1-N2 173.65(11), O1-Pd2-N1 174.78(11), C44-Pd1-N2 81.66(14), C3-Pd2-N1 81.26(13), C44-Pd1-O4 93.70(12), C3-Pd2-O1 93.56(12), O4-Pd1-O2 89.13(10), O1-Pd2-O3 89.42(10), N2-Pd1-O2 95.33(12), N1-Pd2-O3 95.78(10).

Figure 4. XRD molecular structure of compound 1d. Selected bond distances $(\AA)$ and angles (deg): Pd1-C1 1.957(4), Pd1-N1 2.038(3), Pd1-O1 2.141(3), Pd1-O2 2.050(3), Pd(1)-Pd(1) 3.2037(6), O1-Pd1-C1 171.07(13), N1-Pd1-O2 172.97(12), C1-Pd1-N1 81.19(14), C1-Pd1-O2 92.50(15), O2-Pd1-O1 87.34(11), N1-Pd1-O1 98.40(12).

Figure 5. XRD molecular structure of compound 4a. Selected bond distances $(\AA)$ and angles (deg): Pd1-C31 2.015(2), Pd1-Cl1 2.3508(6), Pd1-N1 2.1028(19), Pd1-P1 2.2695(6), N1-Pd1-P1 176.59(5), C(31)-Pd(1)-Cl(1) 170.94(7), C31-Pd1-N1 80.70(8), N1-Pd1-Cl1 90.86(6), P1-Pd1-Cl1 92.42(2), C31-Pd1-P1 96.09(7).

Figure 6. XRD molecular structure of compound $4 \mathrm{~b}$. Selected bond distances $(\AA)$ and angles (deg): Pd1-C23 2.0226(19), Pd1-C11 2.3647(10), Pd1-N1 2.1162(17), Pd1-P1 2.2651(9), Cl1-Pd1-C23 172.91(6), P1-Pd1-N1 175.62(5), N1-Pd1-C23 81.11(7), Cl1-Pd1-N1 91.83(5), Cl1-Pd1-P1 92.54(3), P1-Pd1-C23 94.52(6).

Figure 7. XRD molecular structure of compound 4c. Selected bond distances $(\AA)$ and angles (deg): $\mathrm{Pd}(1)-\mathrm{C}(1)$ 2.0135(19), $\mathrm{Pd}(1)-\mathrm{N}(1)$ 2.0964(16), $\mathrm{Pd}(1)-\mathrm{P}(1)$ 2.2639(6), $\mathrm{Pd}(1)-\mathrm{Cl}(1)$ 2.3837(5), $\mathrm{C}(1)-\mathrm{Pd}(1)-\mathrm{N}(1)$ 80.69(7), C(1)-Pd(1)-P(1) 93.70(6), N(1)-Pd(1)-P(1) 174.15(5), C(1)-Pd(1)-Cl(1) 173.10(6), $\mathrm{N}(1)-\mathrm{Pd}(1)-\mathrm{Cl}(1)$ 92.62(5), $\mathrm{P}(1)-\mathrm{Pd}(1)-\mathrm{Cl}(1)$ 92.942(19).

Figure 8. Interaction of pBluescript SK + plasmid DNA $(0.8 \mu \mathrm{g})$ with increasing concentrations of compounds under study, cisplatin and ethidium bromide. Lane 1: DNA only. Lane 2: $2.5 \mu \mathrm{M}$. Lane 3: 5 
$532 \mu \mathrm{M}$. Lane 4: $10 \mu \mathrm{M}$. Lane 5: $25 \mu \mathrm{M}$. Lane 6: $50 \mu \mathrm{M}$. Lane 7: $100 \mu \mathrm{M}$. Lane 8: $150 \mu \mathrm{M}$. Lane 9: 200 $533 \mu \mathrm{M} ; \mathrm{ccc}=$ supercoiled closed circular DNA; oc $=$ open circular DNA.

534

535 Figure 9. Analysis of $2 \mathrm{~b}$ and $2 \mathrm{~d}$ as putative DNA intercalators or topoisomerase I inhibitors. Conversion 536 of supercoiled pBluescript plasmid DNA $(0.8 \mu \mathrm{g})$ to relaxed DNA by the action of topoisomerase I (3 537 units) in the absence or in the presence of increasing amounts of compounds $2 b$ and $2 d$ was analyzed by 538 agarose gel stained with ethidium bromide. EB was used as a control of intercalating agent and etoposide 539 (E) as a control of nonintercalating agent. Lane 1: DNA only. Lane 2: $0 \mu \mathrm{M}$ drug. Lane 3: $10 \mu \mathrm{M}$ drug. 540 Lane 4: $25 \mu \mathrm{M}$ drug. Lane 5: $50 \mu \mathrm{M}$ drug. Lane 6: $100 \mu \mathrm{M}$ drug. Except for lane 1, all lanes included 541 topoisomerase I; $\mathrm{ccc}=$ supercoiled closed circular DNA; oc = open circular DNA.

542

543

544

545 
546 Table 1. IC50 $(\mu \mathrm{M})$ Values against the Indicated Cancer Cell Lines and clog P for the Compounds under 547 Studya

\begin{tabular}{|c|c|c|c|c|}
\hline compound & MDA-MB-231 & MCF-7 & HCT-116 & $\operatorname{clog} P^{\prime}$ \\
\hline a & $>100$ & $>100$ & $>100$ & 5.11 \\
\hline Ia & $>100$ & $>100$ & $82 \pm 19$ & 12.10 \\
\hline $2 a$ & $40 \pm 2$ & $30 \pm 9$ & $47 \pm 8$ & 10.35 \\
\hline $3 \mathbf{a}$ & $12 \pm 2$ & $>100$ & $66 \pm 10$ & 11.89 \\
\hline $4 \mathbf{a}$ & $>100$ & $>100$ & $>100$ & 11.01 \\
\hline b & $>100$ & $>100$ & $>100$ & 6.28 \\
\hline Ib & $>100$ & $>100$ & $>100$ & 14.45 \\
\hline $2 b$ & $\geq 100$ & $>100$ & $>100$ & 12.69 \\
\hline $3 b$ & $>100$ & $>100$ & $>100$ & 13.06 \\
\hline $4 b$ & $>100$ & $>100$ & $>100$ & 12.19 \\
\hline c & $>100$ & $>100$ & 94 & 4.58 \\
\hline 1c & $>100$ & $>100$ & $>100$ & 12.77 \\
\hline $2 \mathrm{c}$ & $20 \pm$ nd & $44 \pm 10$ & $31 \pm 3$ & 10.62 \\
\hline $3 \mathrm{c}$ & $>100$ & $>100$ & $>100$ & 12.22 \\
\hline $4 \mathrm{c}$ & $91 \pm$ nd & $>100$ & $65 \pm 8$ & 11.35 \\
\hline d & $>100$ & $80 \pm$ nd & $57 \pm 5$ & 4.89 \\
\hline Id & $>100$ & $>100$ & $98 \pm 28$ & 12.99 \\
\hline $2 d$ & $16 \pm$ nd & $37 \pm 9$ & $27 \pm 2$ & 11.24 \\
\hline 3d & $>100$ & $>100$ & $>100$ & 12.53 \\
\hline $4 d$ & $>100$ & $>100$ & $>100$ & 11.65 \\
\hline e & $>100$ & $>100$ & $>100$ & 2.69 \\
\hline le & $15.0 \pm 1.2^{\circ}$ & $14.0 \pm 4.2$ & $33 \pm 3^{5}$ & 7.48 \\
\hline $2 e$ & $13 \pm 1^{c}$ & $11.0 \pm 1.5$ & $20.0 \pm 0.7$ & 5.73 \\
\hline $3 \mathrm{e}$ & $1.1 \pm 0.3$ & $4.0 \pm 0.5^{5}$ & $18 \pm 2^{c}$ & 9.58 \\
\hline $4 e$ & $1.1 \pm 0.1^{e}$ & $4.1 \pm 0.9^{9}$ & $20 \pm 5^{c}$ & 8.70 \\
\hline $4 f$ & $5.0 \pm 1.2$ & $13.4 \pm 1.5^{5}$ & $11.0 \pm 0.6^{x}$ & 8.70 \\
\hline cisplatinf & $5.0 \pm 1.2$ & $19 \pm 4.5$ & $40.0 \pm 4.4$ & -2.5 \\
\hline
\end{tabular}


552 Table 2. IC50 $(\mu \mathrm{M})$ Values for Compound 3e toward HUVEC Cells in Starving and Normal Culture 553 Conditions $^{\mathrm{a}}$

$\begin{array}{lcc}\text { compound } & \text { HUVEC starving }{ }^{b} & \text { HUVEC normal } \\ 3 \mathrm{e} & 49 \pm \mathrm{nd} & 29 \pm 7 \\ \text { cisplatin }^{c} & 16 \pm 3 & 18 \pm 2\end{array}$

a Data are shown as the mean values of two experiments performed in triplicate with the corresponding standard deviation. cis$\left[\mathrm{PtCl}_{2}\left(\mathrm{NH}_{3}\right)_{2}\right]$ is taken as a reference compound. ${ }^{b}$ Low proliferative culture conditions. 'Highly proliferative culture conditions. 
559 Table 3 Palladium and Platinum Accumulation in the MDAMB-231 Cell Line

compound

$1 \mathrm{~b}$

$2 b$

$3 \mathrm{~b}$

$4 \mathrm{~b}$

le

$2 \mathrm{e}$

$3 e$

$4 \mathrm{e}$

dsplatin
œIl accumulation ${ }^{a}$

$$
\begin{aligned}
0.40 & \pm 0.15 \\
0.56 & \pm 0.09 \\
0.7 & \pm 0.4 \\
0.02 & \pm 0.01 \\
0.2 & \pm 0.1 \\
0.072 & \pm 0.006 \\
0.9 & \pm 0.2 \\
1.6 & \pm 0.6 \\
0.015 & \pm 0.002
\end{aligned}
$$

${ }^{a}$ Cell accumulation for compounds $\mathbf{b}$ and $\mathbf{e}$ and for cisplatin is given as ( $\mathrm{mol}$ of $\mathrm{Pd}$ or of Pt per cell $\pm \mathrm{SD}) \times 10^{-15}$ and was measured by ICP. MS after $4 \mathrm{~h}$ of treatment at $50 \mu \mathrm{M}$ with the indicated compounds. Experiments were performed in duplicate. SD = standard deviation. 
565 Table 4. IC50 $(\mu \mathrm{M})$ Values and Percent of Residual Activity of Cathepsin B at $100 \mu \mathrm{M}$ for 566 Compounds 2a, 2c, 2d, and $3 \mathrm{a}^{\mathrm{a}}$

$\begin{array}{ccc}\text { compound } & \mathrm{IC}_{50}(\mu \mathrm{M}) \text { vs cathepsin B } & \% \text { of residual activity at } 100 \mu \mathrm{M} \\ 2 \mathrm{a} & >100 & 58.0 \pm 0.8 \\ 2 \mathrm{c} & >50 & 47.0 \pm 1.1 \\ 2 \mathrm{~d} & >50 & 45.0 \pm 1.9 \\ 3 \mathrm{a} & >50 & 47.0 \pm 0.9 \\ 1 \mathrm{e}^{b} & >100 & 62.0 \pm 2.1 \\ 2 \mathrm{e}^{b} & >100 & 60.0 \pm 1.7 \\ 3 \mathrm{e}^{b} & >100 & 70.0 \pm 1.5 \\ 4 \mathrm{e}^{b} & >50 & 50.0 \pm 0.9 \\ 4 \mathrm{f}^{b} & >100 & 72.0 \pm 1.0\end{array}$

${ }^{a}$ The enzyme was preincubated for $2 \mathrm{~h}$ with 50 or $100 \mu \mathrm{M}$ of each compound The activity is given as a percentage of the enzyme activity determined in the absence of the test compound. Data are shown as the mean values of the experiment performed in triplicate with the corresponding standard deviation. ${ }^{b}$ Previously reported. ${ }^{20}$

568

569

570

571 
575

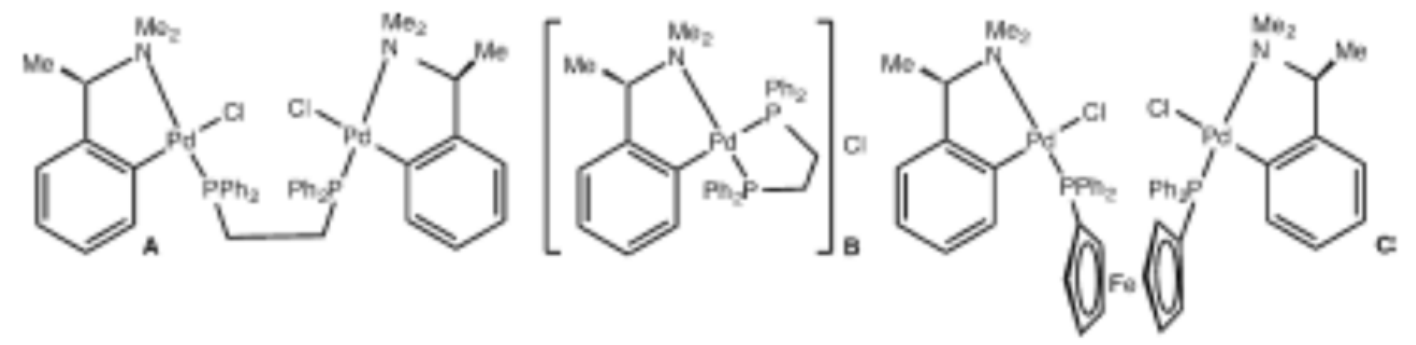

576

577 


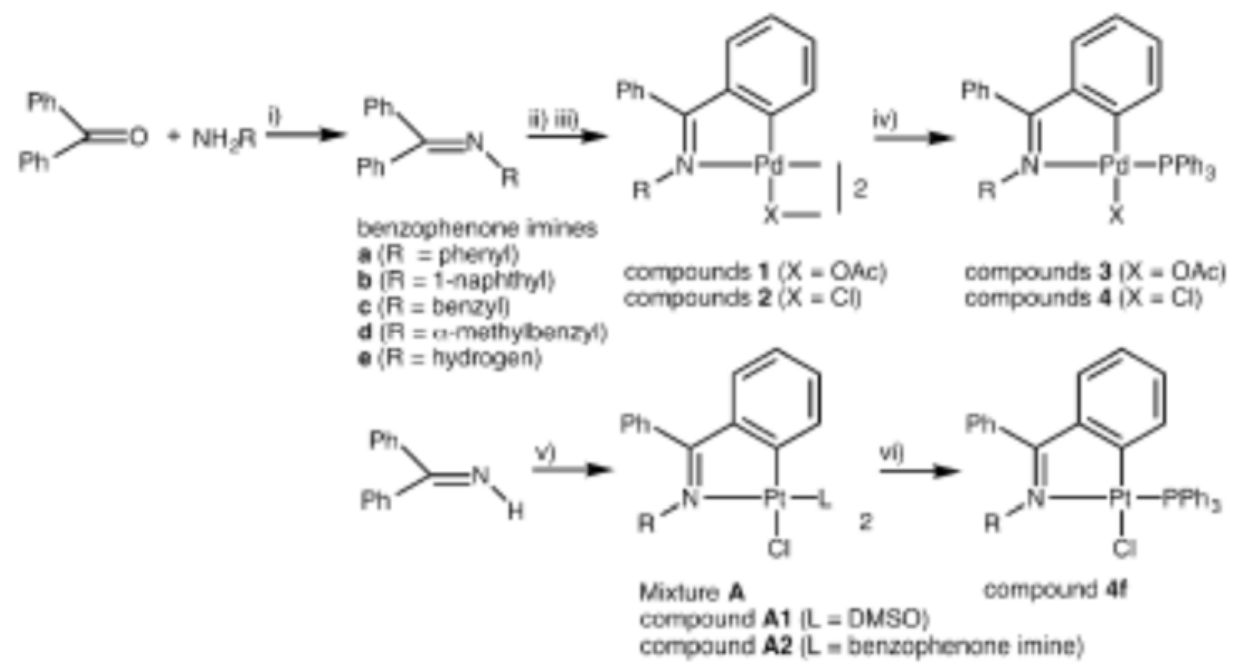

583

584 a Reactions and conditions: (i) TiCl4 (Lewis acid promoter and drying agent) + benzophenone + amine, 585 toluene, $24 \mathrm{~h}$, reflux, molar ratio TiCl4/benzophenone/amine $=1: 1: 5$; (ii) benzophenone imine + $586 \mathrm{Pd}(\mathrm{OAc}) 2, \mathrm{HOAc}, 60^{\circ} \mathrm{C}, 24 \mathrm{~h}$, molar ratio $\mathrm{Pd}(\mathrm{OAc}) 2 /$ benzophenone imine $=1: 1$; (iii) compound $1+$ $587 \mathrm{LiCl}$ excess, acetone, room temperature, $2 \mathrm{~h}$; (iv) compounds 1 or $2+\mathrm{PPh} 3$, acetone, room temperature, $5882 \mathrm{~h}$, molar ratio 1 or $2 / \mathrm{PPh} 3=1: 2$; (v) cis-[PtCl2(DMSO)2], NaOAc (stoichiometric), benzophenone 589 imine (excess), methanol, reflux, $24 \mathrm{~h}$, under N2; (vi) mixture A + PPh3, acetone, room temperature, 2 $590 \mathrm{~h}$, molar ratio mixture $\mathrm{A} / \mathrm{PPh} 3=1: 1$. 
592

593
Figure 2

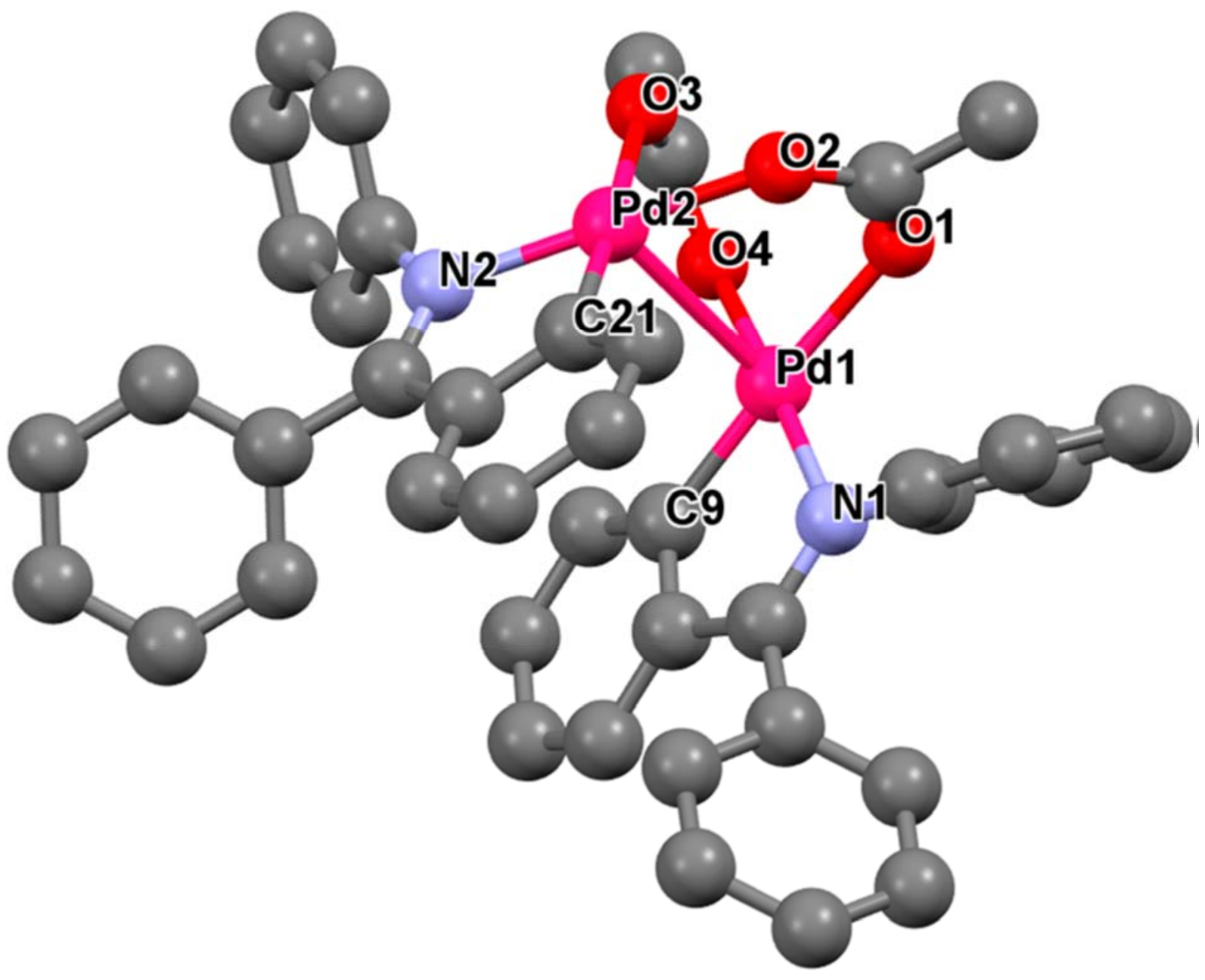

594

595

596

597

598

599 
601

602

603

604

605

606

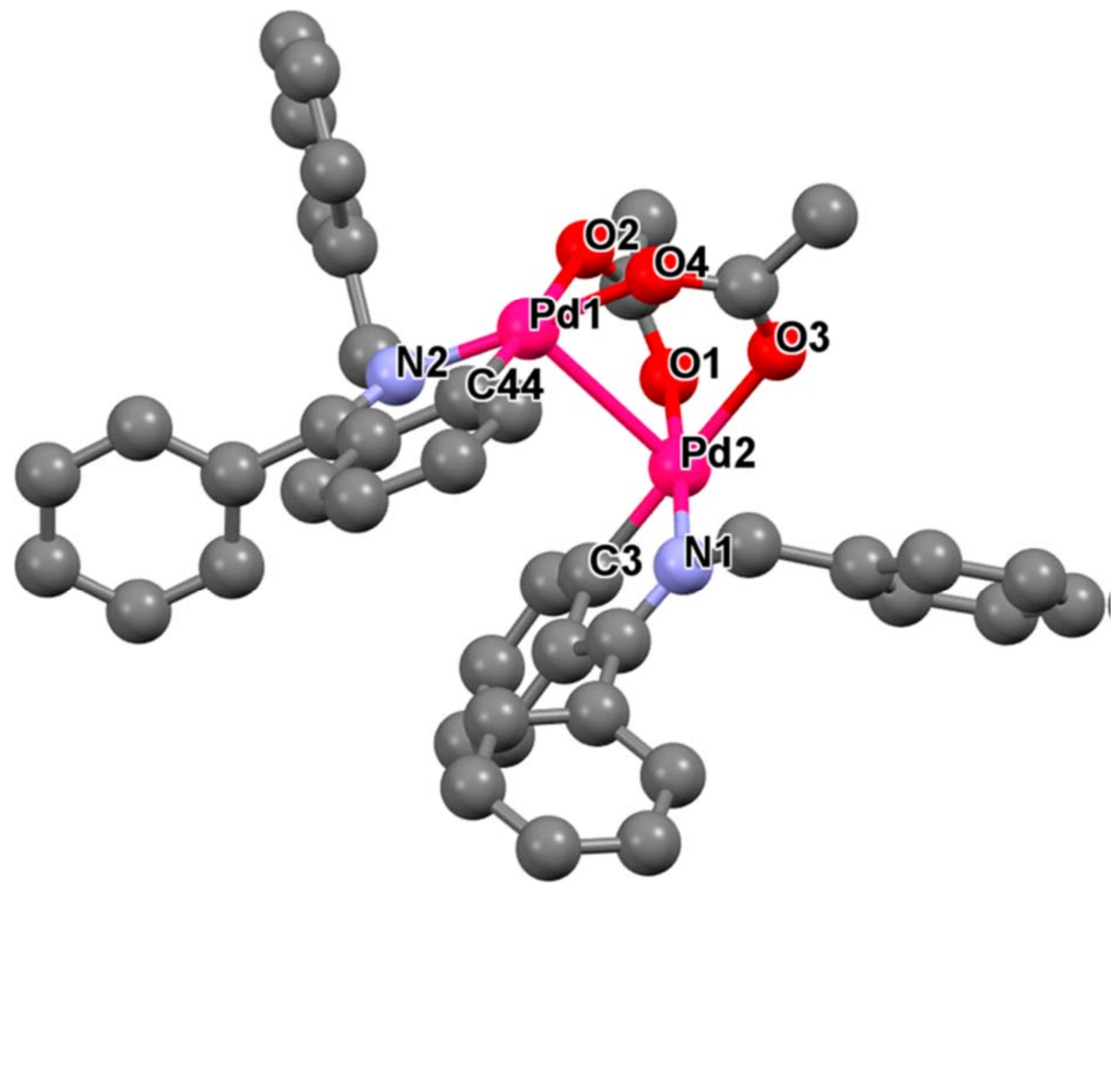


607

608
Figure 4

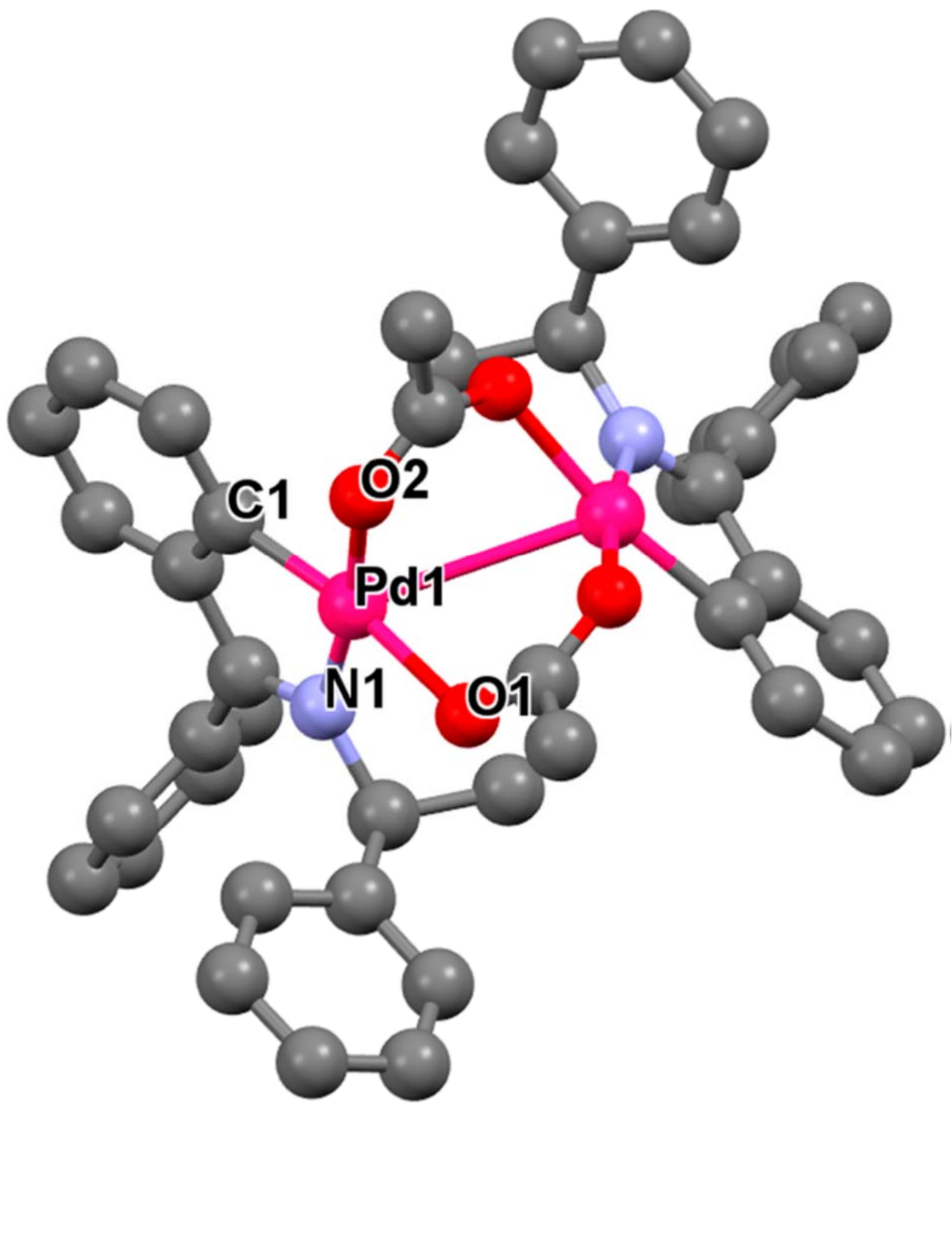


613

614

615

Figure 5

615

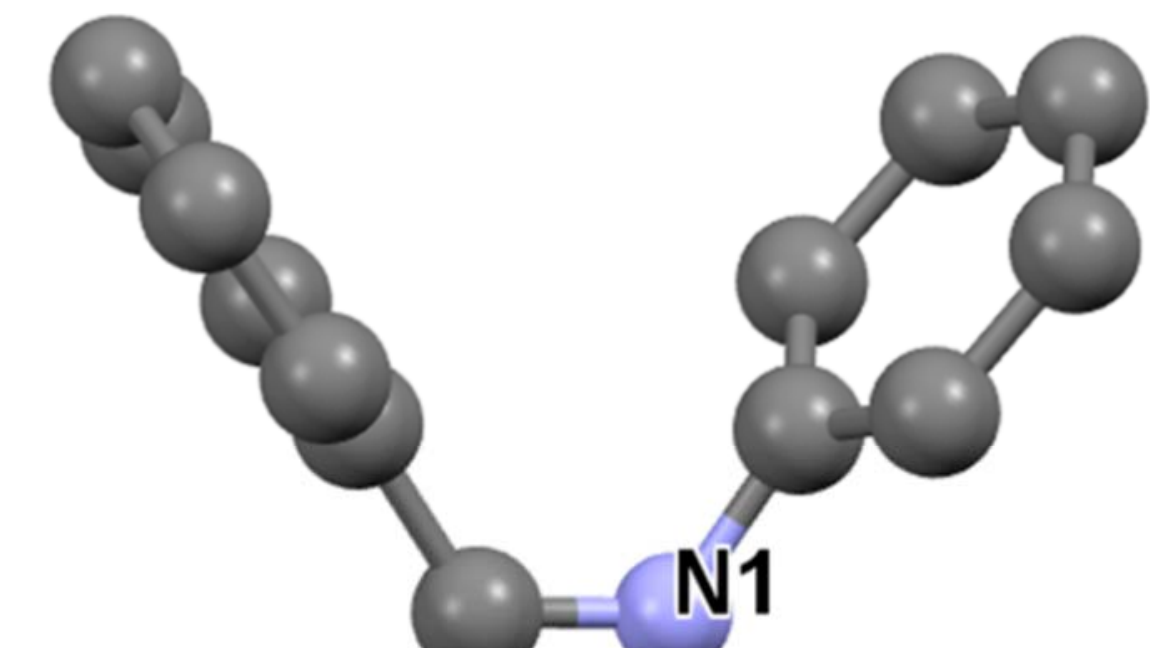

616

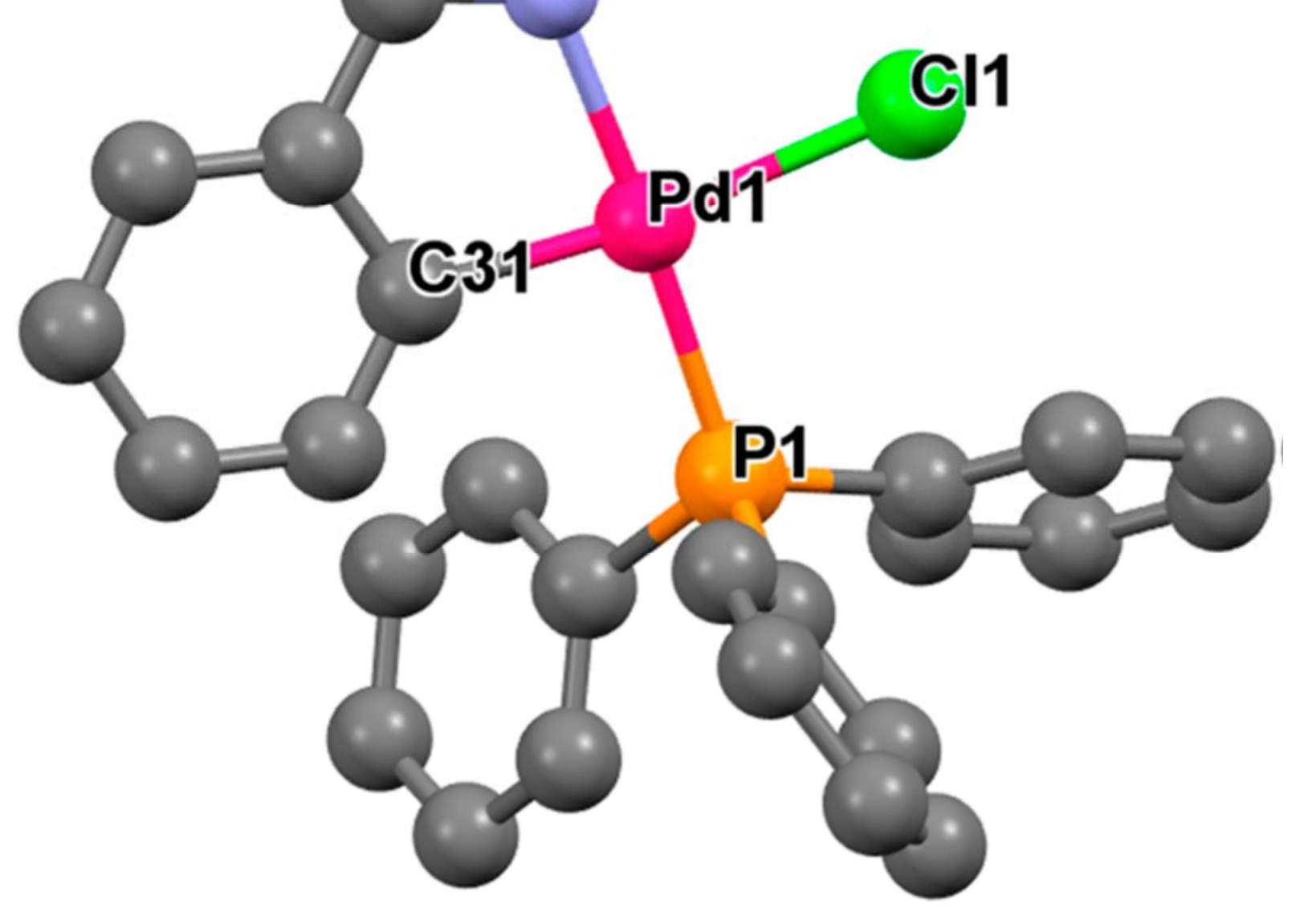

617 
618

619
Figure 6

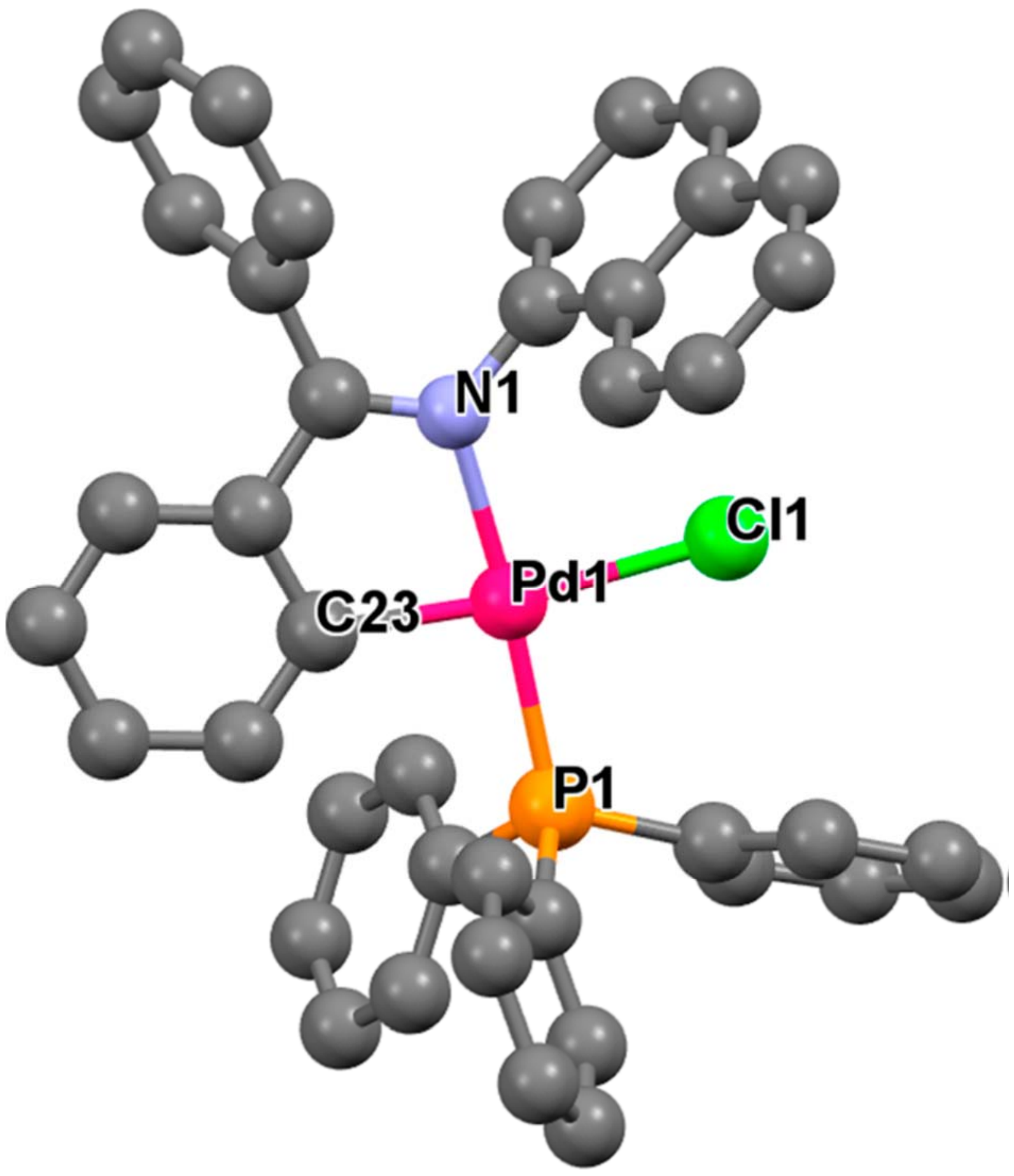


626

627
Figure 7

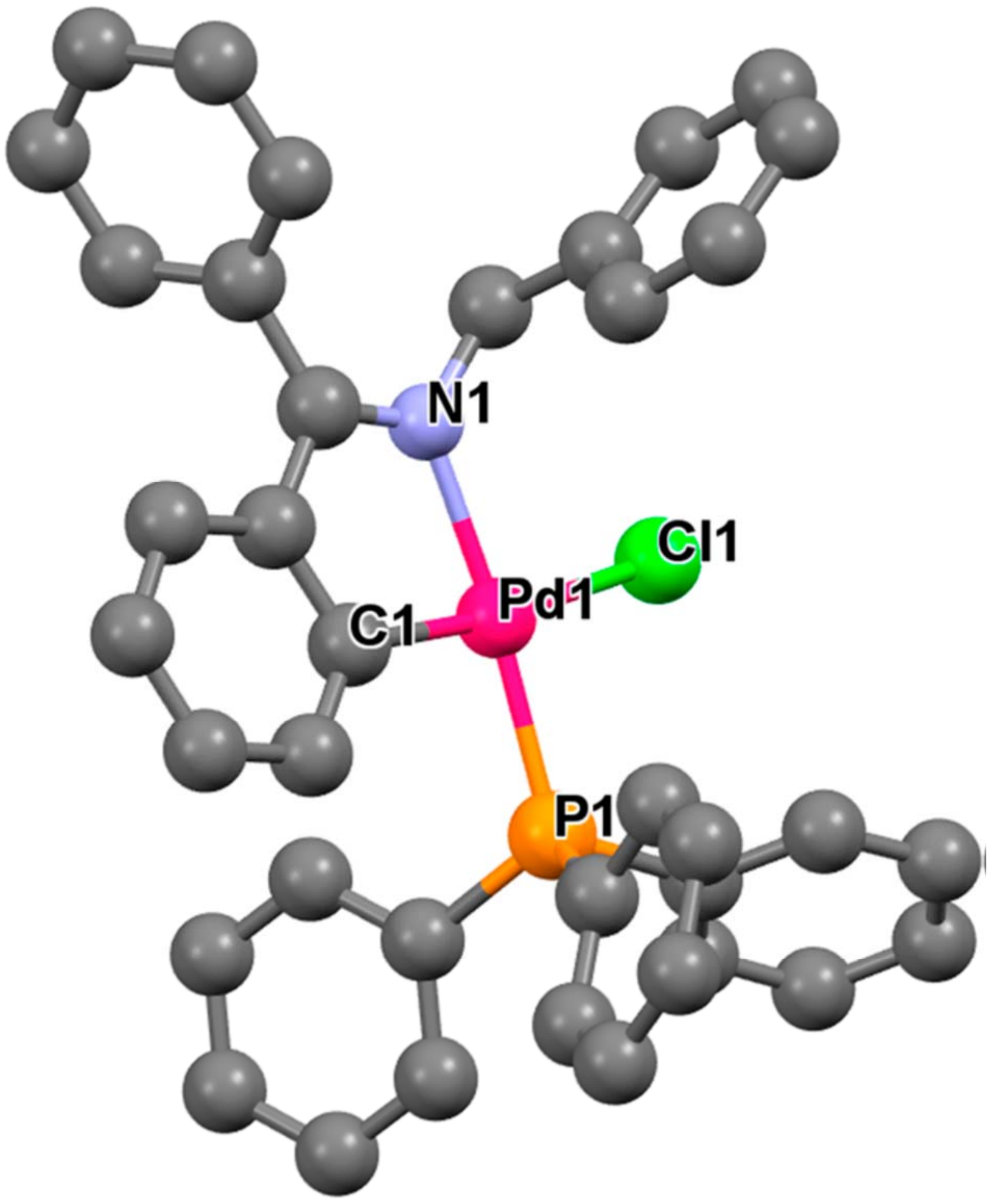

628

629 
633

634

635

636

637

638

639

640

641

642

643

644

645

646

647

648

649

650

651

652

653

654

655

656

657

658

659

660

661

662

663

664
Figure 8
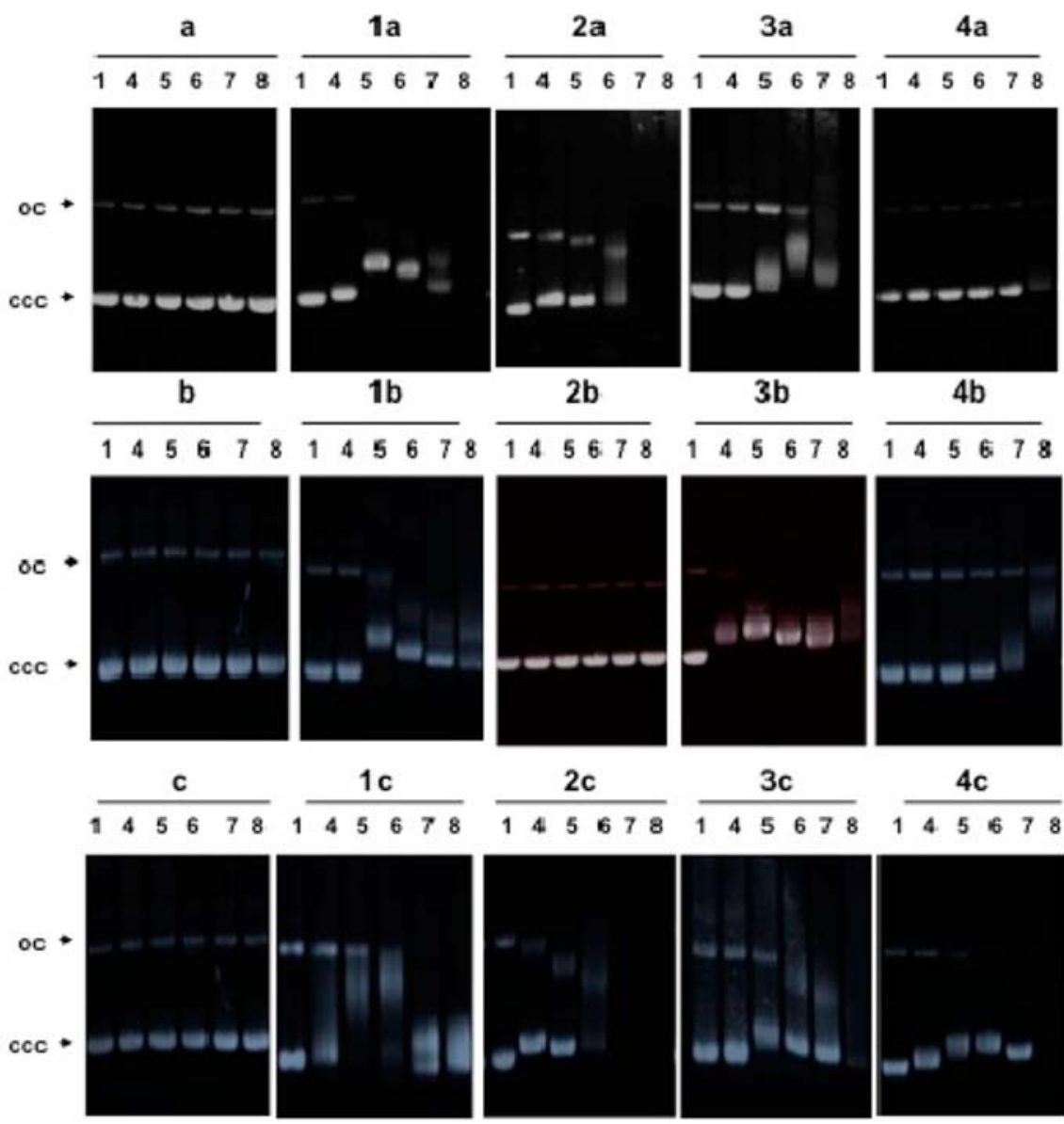

$$
\frac{d}{1456678} \frac{1 d}{145678}
$$

2d
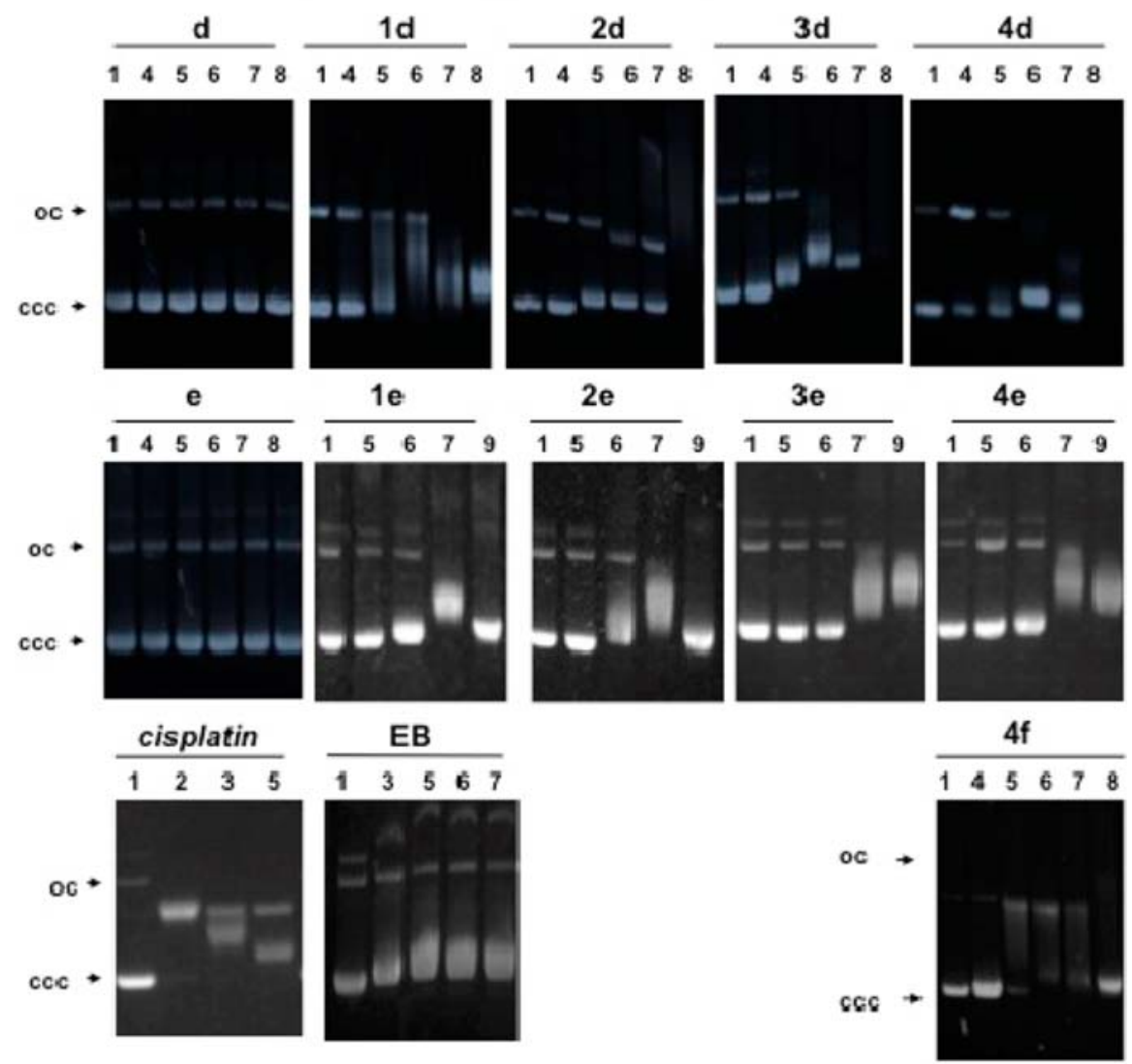
665

666

Figure 9
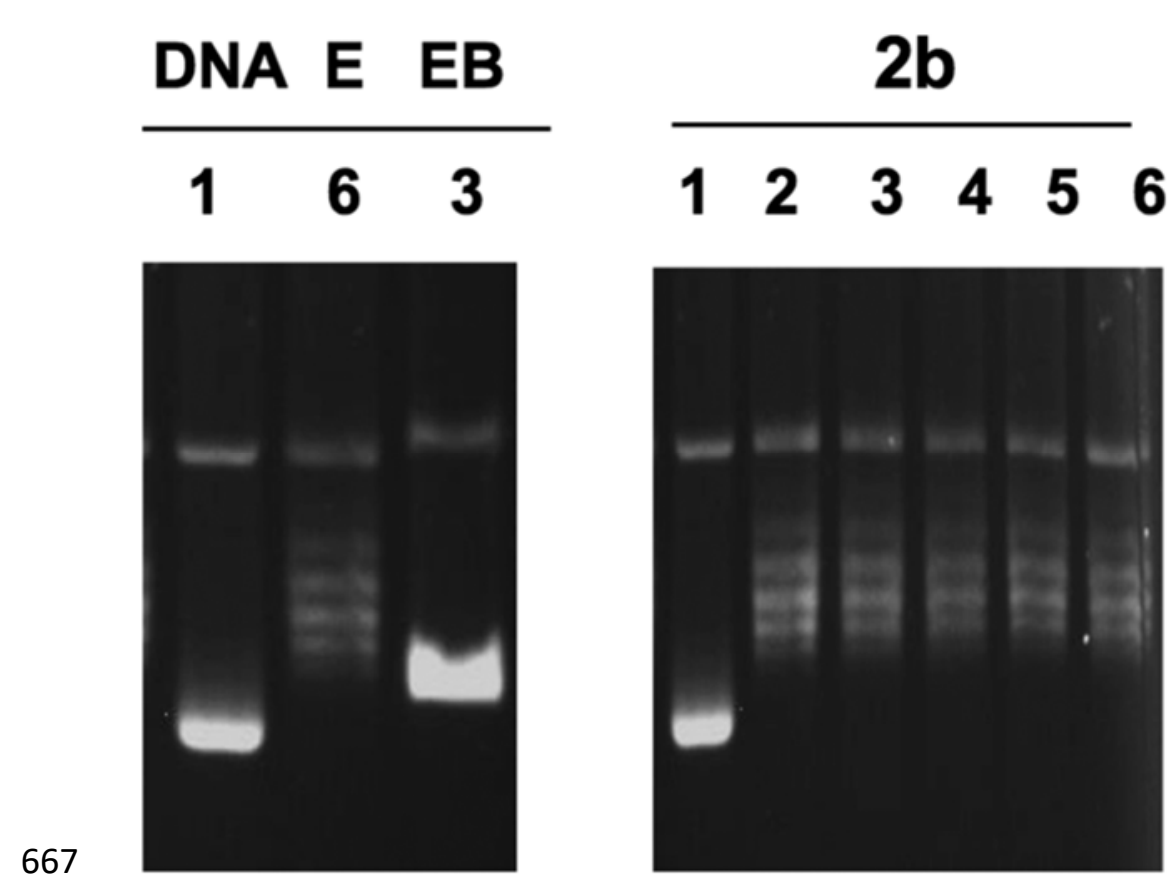

2d
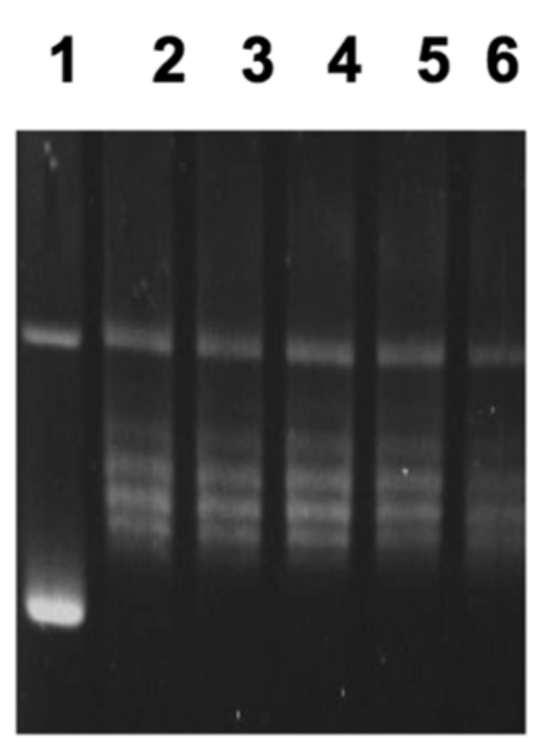